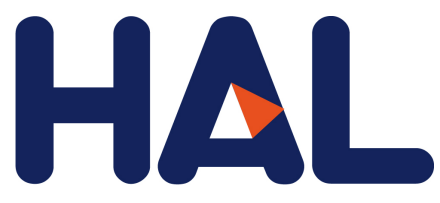

archives-ouvertes

\title{
Fluorescent Derivatives of AC-42 To Probe Bitopic Orthosteric/Allosteric Binding Mechanisms on Muscarinic M1 Receptors
}

Sandrine Daval, Celine Valant, Dominique Bonnet, Esther Kellenberger, Marcel Hibert, Jean-Luc Galzi, Brigitte Ilien, Celine Valant

\section{To cite this version:}

Sandrine Daval, Ceĺine Valant, Dominique Bonnet, Esther Kellenberger, Marcel Hibert, et al.. Fluorescent Derivatives of AC-42 To Probe Bitopic Orthosteric/Allosteric Binding Mechanisms on Muscarinic M1 Receptors. Journal of Medicinal Chemistry, American Chemical Society, 2012, 55 (5), pp.2125-2143. 10.1021/jm201348t . hal-02193850

\section{HAL Id: hal-02193850 \\ https://hal.archives-ouvertes.fr/hal-02193850}

Submitted on 24 Jul 2019

HAL is a multi-disciplinary open access archive for the deposit and dissemination of scientific research documents, whether they are published or not. The documents may come from teaching and research institutions in France or abroad, or from public or private research centers.
L'archive ouverte pluridisciplinaire HAL, est destinée au dépôt et à la diffusion de documents scientifiques de niveau recherche, publiés ou non, émanant des établissements d'enseignement et de recherche français ou étrangers, des laboratoires publics ou privés. 


\title{
Fluorescent Derivatives of AC-42 To Probe Bitopic Orthosteric/ Allosteric Binding Mechanisms on Muscarinic M1 Receptors
}

\author{
Sandrine B. Daval, ${ }^{\dagger, \S}$ Céline Valant, ${ }^{\ddagger}, \|$ Dominique Bonnet, ${ }^{\ddagger}$ Esther Kellenberger, ${ }^{\ddagger}$ Marcel Hibert, ${ }^{\ddagger}$ \\ Jean-Luc Galzi, ${ }^{\dagger}$ and Brigitte Ilien* ${ }^{*}$ \\ †Unité Biotechnologie et Signalisation Cellulaire, UMR 7242 CNRS, Ecole Supérieure de Biotechnologie de Strasbourg, Université de \\ Strasbourg, BP 10413, 67412 Illkirch, France \\ ${ }^{\ddagger}$ Laboratoire d'Innovation Thérapeutique, UMR 7200 CNRS, Faculté de Pharmacie, Université de Strasbourg, 74 Route du Rhin, BP \\ 24, 67401 Illkirch, France
}

Supporting Information

ABSTRACT: Two fluorescent derivatives of the M1 muscarinic selective agonist AC-42 were synthesized by coupling the lissamine rhodamine B fluorophore (in ortho and para positions) to AC42- $\mathrm{NH}_{2}$. This precursor, prepared according to an original seven-step procedure, was included in the study together with the LRB fluorophore (alone or linked to an alkyl chain). All these compounds are antagonists, but examination of their ability to inhibit or modulate orthosteric $\left[{ }^{3} \mathrm{H}\right] \mathrm{NMS}$ binding

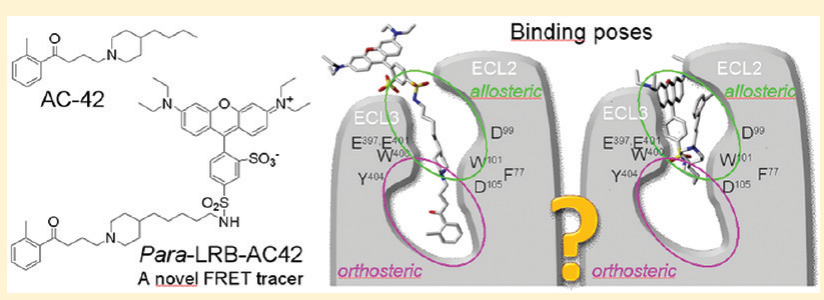
revealed that para-LRB-AC42 shared several properties with AC-42. Carefully designed experiments allowed para-LRB-AC42 to be used as a FRET tracer on EGFP-fused M1 receptors. Under equilibrium binding conditions, orthosteric ligands, AC-42, and the allosteric modulator gallamine behaved as competitors of para-LRB-AC42 binding whereas other allosteric compounds such as WIN 51,708 and $\mathrm{N}$-desmethylclozapine were noncompetitive inhibitors. Finally, molecular modeling studies focused on putative orthosteric/allosteric bitopic poses for AC-42 and para-LRB-AC42 in a 3D model of the human M1 receptor.

\section{INTRODUCTION}

Despite a well-known implication of muscarinic acetylcholine receptors (mAChRs) in a number of physiopathological processes, ${ }^{1,2}$ fine-tuning of M1-M5 receptor subtypes activity through the use of highly selective ligands remained an almost insurmountable challenge until the development of novel compounds able to modulate or stimulate these receptors through allosteric binding sites. ${ }^{3-5}$ Topographically distinct from the conserved orthosteric binding domain where the endogenous agonist acetylcholine and most classical ligands bind in a competitive manner, allosteric sites are probably numerous and diverse (though yet poorly resolved) across the five receptor subtypes. ${ }^{4,5}$ In addition to offering the potential for selective receptor targeting, allosteric ligands may stabilize different receptor conformational and functional states (relative to orthosteric ligands) and therefore instigate a distinct repertoire of receptor signaling and regulatory properties. ${ }^{6,7}$

Allosteric modulators, without detectable effect on their own, reveal their impact on receptor properties when binding concomitantly with an orthosteric ligand. The formation of such ternary complexes is accompanied by conformational rearrangements that result in alterations in ligand affinity, potency, efficacy, subtype, and/or functional selectivity. ${ }^{6,8} \mathrm{~A}$ range of muscarinic modulators has been described, ${ }^{4}$ with their therapeutic potential best illustrated by novel selective allosteric enhancers of acetycholine binding (and function) at M1 or M4 receptors. $^{3,5}$
The properties of the M1-preferring agonist $N$-desmethylclozapine $^{9}$ and of a growing series of novel agonists with unprecedented high functional selectivity at human M1 receptors, such as $\mathrm{AC}-42^{10,11}$ and its $\mathrm{AC}-260584^{12}$ or $77-\mathrm{LH}-$ $28-1^{13}$ analogues, TBPB, ${ }^{14}$ and the more recent LuAE5 $51090^{15}$ and VU0357017 ${ }^{16}$ compounds (Figure 1), raise the exciting possibility that they may provide useful therapeutics for cognitive impairment. ${ }^{14,17,18}$ They exhibit functional selectivity toward subsets of signaling pathways ${ }^{19}$ and appear to stabilize receptor conformations less prone to downstream regulatory programs than orthosteric agonists. ${ }^{20,21}$

These novel compounds are commonly referred to as allosteric agonists on the basis of their insensitivity to the mutation of the critical Tyr381 (residue 6.51, using the Ballesteros and Weinstein convention ${ }^{22}$ ) orthosteric residue and of their ability to decrease the dissociation rate of the orthosteric antagonist $\left[{ }^{3} \mathrm{H}\right] \mathrm{N}$-methylscopolamine. Note that $\mathrm{N}$ desmethylclozapine only fulfills the first criterion for an allosteric interaction at the M1 subtype. The competitive ${ }^{13,23,24}$ or noncompetitive ${ }^{11,12,14,15}$ character of the novel agonists, when tested against orthosteric ligands in equilibrium binding or functional interaction studies, is still a matter of debate, as true competition is often difficult to distinguish from very strong negative binding cooperativity. ${ }^{8}$ Most of them bind to all muscarinic receptors with similar affinity, whereas they display

Received: October 8, 2011 

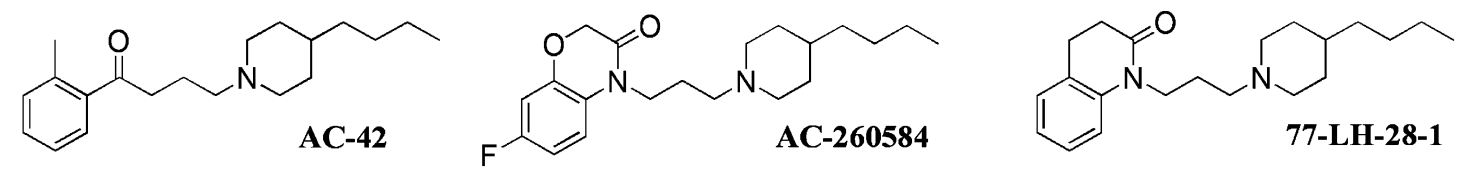<smiles>CCOC(=O)N1CCC(NCCNC(=O)c2ccccc2C)CC1</smiles><smiles>Cc1ccccc1CN1CCC(N2CCC(n3c(=O)[nH]c4ccccc43)CC2)CC1</smiles>

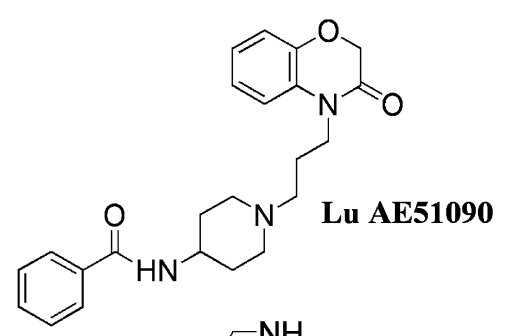<smiles>CC[N+](CC)(CC)CCOc1cccc(OCC[N+](CC)(CC)CC)c1OCC[N+](CC)(CC)CC</smiles>

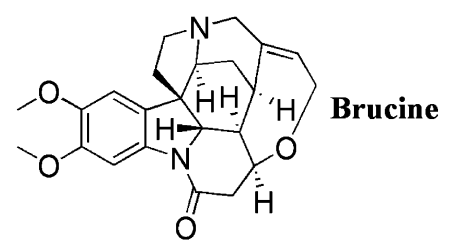<smiles>Clc1ccc2c(c1)N=C(N1CCNCC1)c1ccccc1N2</smiles><smiles>Cc1ccc2c(c1)C(=O)N(CCC[N+](C)(C)C)C2=O</smiles>

Figure 1. Chemical structures of novel muscarinic agonists and of well-known allosteric modulators. Selected compounds are cited in this paper. Some of them (AC-42, NDMC, gallamine, brucine and Win 51,708) were also used as pharmacological tools in several experiments presented in this paper.

weak efficacies at M2-M5 subtypes, suggesting that activation mechanisms may vary among subtypes. ${ }^{25}$ Mutagenesis mapping studies on the M1 receptor, combined with binding and activation profiling of various muscarinic agonists, provide evidence for the existence of multiple activation switches, some of which can be selectively exploited by novel agonists whereas others are used by all agonist classes. $12,23,26$

Altogether, these observations tend to indicate that the novel agonists may explore the well-conserved orthosteric binding pocket and gain functional M1 selectivity from additional interactions with less conserved residues and/or from the ability to elicit subtype-specific conformational rearrangements. ${ }^{23,24}$ It has been recently suggested that these agonists might be bitopic in that they may recognize epitopes within the orthosteric site and part of an allosteric site. ${ }^{24}$ Yet ligand docking into M1 receptor homology models provides a confounding picture of the domains explored by these compounds: AC-42 and TBPB share a binding pocket distinct from the orthosteric site, ${ }^{26} \mathrm{AC}-42$ and 77-LH-28-1 better adopt a bitopic binding mode in extending down into the orthosteric site as well as up toward a less buried allosteric site. ${ }^{24}$ Whether these compounds explore a subsidiary binding pocket overlapping with ${ }^{24}$ or distinct from ${ }^{23}$ the "common" allosteric site used by modulators such as gallamine remains unclear.

In this work, we report on the synthesis and pharmacological characterization of two lissamine rhodamine $B$ (LRB) derivatives (ortho and para isomers) of AC-42 to address some of these still open questions. We aimed at obtaining a fluorescent agonist, an allosteric tracer, or a bitopic ligand amenable to be investigated through radioligand based and fluorescence resonance energy transfer (FRET) based binding studies. ${ }^{27,28}$ Functional experiments were first undertaken using HEK cells stably expressing a series of EGFP-fused human M1 receptors, with progressive deletion of the receptor $\mathrm{N}$-terminus, in order to examine the role of this domain as a possible determinant of AC-42 agonism and to define the pharmacological nature and potency of the various compounds. Equilibrium and kinetic $\left[{ }^{3} \mathrm{H}\right] \mathrm{NMS}$ binding studies were conducted on living cells expressing the $\operatorname{EGFP}(\Delta 17) \mathrm{hM} 1$ receptor to unravel the orthosteric or allosteric nature of the fluorescent derivatives. Using the same receptor chimera, we carefully designed the experimental conditions for FRET measurements, evaluated the potential of the LRB derivatives as FRET probes, focusing on the binding parameters of the para-LRB-AC42 isomer under equilibrium and kinetic conditions and on the ability of several prototypical compounds to modulate its affinity properties. Finally, molecular modeling studies were undertaken to get structural insights on putative binding domains for AC-42 and para-LRB-AC42 in the M1 receptor. Altogether, we describe a fluorescent bitopic tracer that shares many properties with its parent AC-42 compound and overlaps both the orthosteric site and the allosteric gallamine site. Such a combination of $\left[{ }^{3} \mathrm{H}\right] \mathrm{NMS}$ and FRETbased binding assays proves useful to study bitopic ligands and may help to discover new muscarinic allosteric agents.

\section{RESULTS}

Two lissamine rhodamine $\mathrm{B}$ derivatives of AC-42 (ortho-LRBAC42 and para-LRB-AC42) were synthesized in order to examine their binding properties at M1 muscarinic receptors 
<smiles>CCCCC1CCN(CCCC(=O)c2ccccc2C)CC1</smiles><smiles>Cc1ccccc1C(=O)CCCN1CCC(CCCCCN)CC1</smiles><smiles>CCNCCCC(=O)c1ccccc1C</smiles><smiles>CCN(CC)c1ccc2cc3c(-c4ccc(S(=O)(=O)[O-])cc4S(=O)(=O)NCCCCCC4CC[IH]CC4)cc(=[N+](CC)CC)cc-3oc2c1</smiles>

ortho-LRB-AC42, 2 a

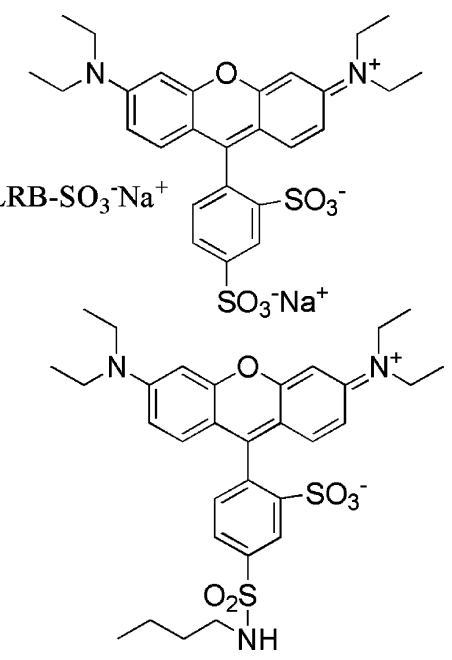

para-LRB-nbutyl, 20

Figure 2. Chemical structures of AC-42 and lissamine rhodamine B derivatives.

Table 1. Spectroscopic Parameters of Fluorophores and of Their Conjugates

\begin{tabular}{|c|c|c|c|c|c|c|c|c|}
\hline \multirow[b]{3}{*}{ molecule } & \multicolumn{4}{|c|}{ absorption } & \multicolumn{4}{|c|}{ fluorescence } \\
\hline & \multicolumn{2}{|l|}{$\mathrm{MeOH}$} & \multicolumn{2}{|l|}{ buffer } & \multirow{2}{*}{$\frac{\mathrm{MeOH}}{\lambda_{\max }(\mathrm{nm})}$} & \multirow{2}{*}{$\frac{\text { buffer }}{\lambda_{\max }(\mathrm{nm})}$} & \multicolumn{2}{|c|}{ donor/acceptor pair ${ }^{a}$} \\
\hline & $\varepsilon \times 10^{-3}\left(\mathrm{M}^{-1} \cdot \mathrm{cm}^{-1}\right)$ & $\lambda_{\max }(\mathrm{nm})$ & $\varepsilon \times 10^{-3}\left(\mathrm{M}^{-1} \cdot \mathrm{cm}^{-1}\right)$ & $\lambda_{\max }(\mathrm{nm})$ & & & $\begin{array}{l}\text { spectral overlap } \\
\left(\mathrm{cm}^{3} \cdot \mathrm{M}^{-1}\right) \times 10^{13}\end{array}$ & $\begin{array}{c}\text { Förster radius } \\
(\AA)\end{array}$ \\
\hline LRB-SO ${ }_{2} \mathrm{Cl}^{b}$ & 88 & 568 & & & 583 & & & \\
\hline LRB-SO ${ }_{3}^{-} \mathrm{Na}^{+}$ & & 556 & & 564 & 574 & 582 & & \\
\hline para-LRB- $n$-butyl & 125 & 561 & 88 & 569 & 579 & 587 & $1.8 \pm 0.1(n=3)$ & $51.2 \pm 0.4(n=3)$ \\
\hline para-LRB-AC42 & 125 & 561 & 88 & 569 & 579 & 587 & $1.8 \pm 0.1(n=3)$ & $51.2 \pm 0.4(n=3)$ \\
\hline ortho-LRB-AC42 & 52 & 563 & $(33-42)$ & 569 & 582 & 587 & nd & nd \\
\hline
\end{tabular}

${ }^{a}$ Spectral overlap $(J)$ and Förster radius $\left(R_{0}\right)$ values for each donor-acceptor pair are from measurements in Hepes buffer and are determined as reported in Supporting Information Procedures. Values are the mean \pm SE for three independent determinations. nd, not determined. ${ }^{b}$ Spectroscopic parameters for LRB sulfonyl chloride. ${ }^{62}$

Scheme 1. Synthesis of Para- and Ortho-LRB-AC42 Derivatives 2a, $\mathbf{b}^{a}$

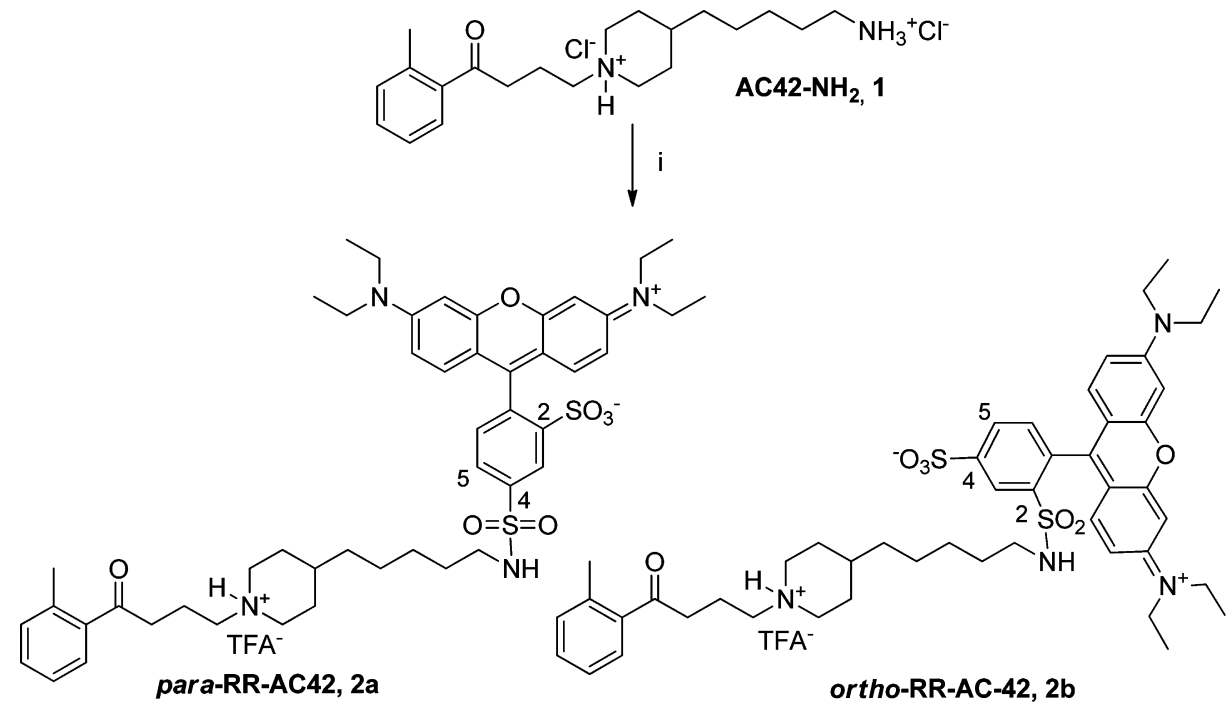

${ }^{a}$ Reagents: (i) (a) lissamine rhodamine B sulfonyl chloride ( $\mathrm{LRB}_{-} \mathrm{SO}_{2} \mathrm{Cl}$ ), $\mathrm{NEt}_{3}, \mathrm{CHCl}_{3}$, rt, overnight; (b) purification by RP-HPLC (solvent A, $\mathrm{H}_{2} \mathrm{O} /$ TFA $0.1 \%$; solvent $\mathrm{B}, \mathrm{CH}_{3} \mathrm{CN} / \mathrm{TFA} 0.1 \%$ ).

and their potential as allosteric tracers under FRET conditions (Figure 2). The lissamine rhodamine B fluorophore (LRB$\left.\mathrm{SO}_{3}{ }^{-} \mathrm{Na}^{+}\right)$, its close derivative with an aliphatic butyl tail mirroring that of AC-42 (para-LRB- $n$-butyl), and the AC42-
$\mathrm{NH}_{2}$ synthetic precursor were also included in this study to evaluate the contribution of individual structural moieties to overall properties of the fluorescent AC-42 derivatives. The lissamine rhodamine B dye was selected for its excellent 
chemical and photochemical stability and for appropriate spectroscopic properties as an energy acceptor from excited EGFP (Supporting Information Figure S1, Table 1).

Chemistry. Previous structure-activity relationship studies have shown that subtle modifications of the 2-methylacetophenone moiety of AC-42 led to variability in agonist potency and receptor subtype selectivity. ${ }^{12,13,29}$ We therefore decided to introduce the fluorophore into AC-42 by modifying its more tolerant $n$-butyl side chain. This was done by reacting lissamine rhodamine B sulfonyl chloride with $\mathrm{AC} 42-\mathrm{NH}_{2} 1$ (Scheme 1).

All our attempts to access to AC42- $\mathrm{NH}_{2} \mathbf{1}$ following protocols previously reported for AC-42 synthesis (U.S. Patent US 6,528,529 B1) failed. An original seven-step process was thus designed, starting from the commercially available $o$ tolylmagnesium bromide (Scheme 2). Condensation of the latter with succinic anhydride led to the acid $3^{30}$ which was subsequently converted into methyl ester 4 . Protection of the

Scheme 2. Synthesis of $\mathrm{AC} 42-\mathrm{NH}_{2} 1^{a}$

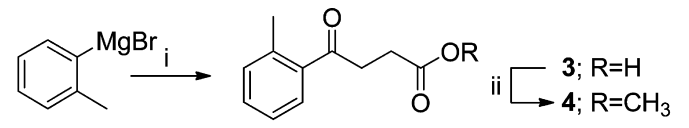

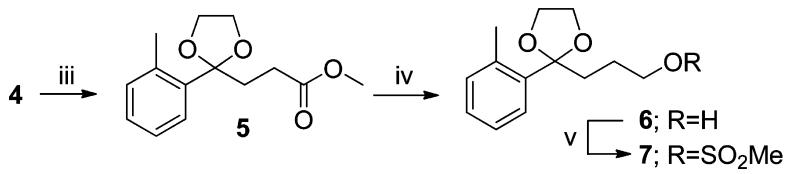

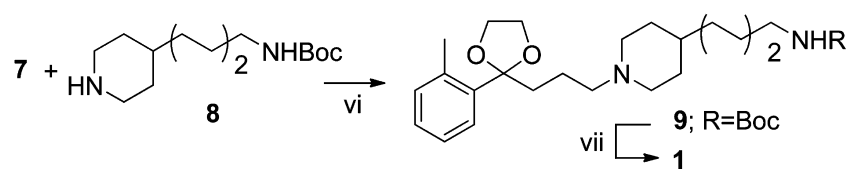

${ }^{a}$ Reagents: (i) succinic anhydride, THF, -78 to $0{ }^{\circ} \mathrm{C}$, then $2 \mathrm{~h}$, rt; (ii) $\mathrm{H}_{2} \mathrm{SO}_{4}, \mathrm{MeOH}$, reflux, overnight; (iii) ethylene glycol, $p$-TsOH, benzene, 2 days; (iv) $\mathrm{LiAlH}_{4}$, ether, $0{ }^{\circ} \mathrm{C}, 1 \mathrm{~h}$; (v) $\mathrm{MeSO}_{2} \mathrm{Cl}, \mathrm{NEt}_{3}, 2$ h, rt; (vi) $\mathrm{NEt}_{3}, \mathrm{CH}_{3} \mathrm{CN}$, sealed tube, $110{ }^{\circ} \mathrm{C}$; (vii) $1 \mathrm{~N} \mathrm{HCl} / \mathrm{Et}_{2} \mathrm{O}$.

ketone group was performed in the presence of ethylene glycol in acidic catalysis to form acetonide $5 .{ }^{31}$ The methyl ester was then reduced into alcohol 6 in the presence of $\mathrm{LiAlH}_{4}$ in dry ether. Conversion of the alcohol into methyl sulfonate 7 was performed in the presence of methanesulfonyl chloride. The nucleophilic displacement of mesylate moiety by the piperazine derivative 8 gave access to compound 9. A subsequent treatment with $\mathrm{HCl}$ enabled the simultaneous deprotection of the ketone and the amino groups, leading to $\mathrm{AC} 42-\mathrm{NH}_{2} 1$ obtained as a chlorhydrate salt in a $5 \%$ overall yield.

The synthesis of piperazine $\mathbf{8}$ involved a four-step process starting from commercially available 4-piperidone 10 (Scheme 3). Protection of the amino group with a benzyloxycarbonyl moiety was followed by the formation of triflate 12 in the presence of $\mathrm{N}$-phenyltrifluoromethanesulfonimide. ${ }^{32}$ A Sonogashira coupling reaction with alkyne 13 gave access to compound $14^{33,34}$ which was treated in the presence of $\mathrm{H}_{2}$ / $\mathrm{PtO}_{2}$ to perform simultaneously the hydrogenolysis of the $\mathrm{Cbz}$ protecting group and the hydrogenation of the alkyne moiety. Following this approach, piperazine 8 was obtained in a $44 \%$ overall yield.

$N$-Boc protected pent-4-yne-1-amino 13 was obtained following an original four-step process, starting from commercially available ethyl oxamate 15 (Scheme 4). ${ }^{35}$ First, the conversion of the latter into isocyanate $\mathbf{1 6}$ was achieved in
Scheme 3. Compound 8 Preparation ${ }^{a}$
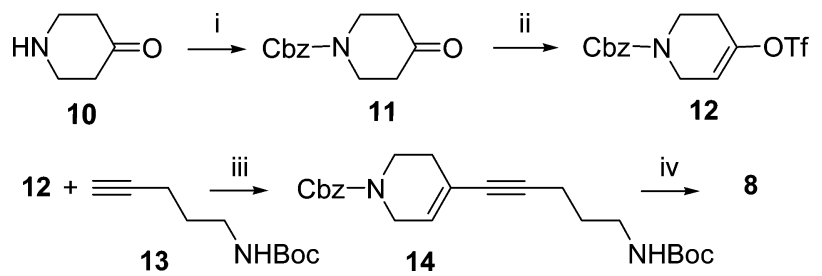

${ }^{a}$ Reagents: (i) BzOCOCl, $\mathrm{NaOH} 10 \%, 0{ }^{\circ} \mathrm{C}$ to rt, $2 \mathrm{~h}, \mathrm{rt}$; (ii) $\mathrm{C}_{6} \mathrm{H}_{5} \mathrm{~N}\left(\mathrm{SO}_{2} \mathrm{CF}_{3}\right)_{2}$, THF, LDA, -78 to $0{ }^{\circ} \mathrm{C}, 3 \mathrm{~h}$; (iii) $\mathrm{PdCl}_{2}\left(\mathrm{PPh}_{3}\right)_{2}$, CuI, $\mathrm{NEt}_{3}$, THF, rt, 6 h; (iv) $\mathrm{H}_{2}, \mathrm{PtO}_{2}, \mathrm{EtOH}, \mathrm{AcOH}$ cat., rt, 65 psi, overnight.

the presence of oxalyl chloride. A subsequent alkylation with $t$ $\mathrm{BuOH}$ led to the $\mathrm{N}$-Boc protected compound 17 which was

Scheme 4. Compound 13 Preparation ${ }^{a}$

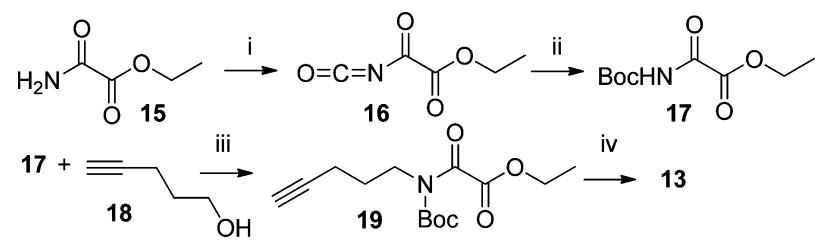

${ }^{a}$ Reagents: (i) ClCOCOCl, $\mathrm{CH}_{2} \mathrm{Cl}_{2}$, reflux, overnight; (ii) $t$ - $\mathrm{BuOH}$, toluene, $40{ }^{\circ} \mathrm{C}$, overnight; (iii) $\mathrm{DEAD}, \mathrm{PPh}_{3}$, THF, rt, overnight; (iv) $\mathrm{LiOH}, \mathrm{H}_{2} \mathrm{O} / \mathrm{THF}$ (1:3), rt, $3 \mathrm{~h}$.

submitted to a Mitsunobu reaction with the commercially available pent-4-yn-1-ol 18 to provide alkyne 19. The final basic hydrolysis of the ethyl ester enabled removal of the ethyl oxalate group to obtain the $\mathrm{N}$-Boc protected alkyne 13 in a $52 \%$ overall yield.

The incorporation of lissamine rhodamine $\mathrm{B}$ (mixed isomers) onto the alkyl chain of $\mathrm{AC} 42-\mathrm{NH}_{2} \mathbf{1}$ was performed using commercial lissamine rhodamine $\mathrm{B}$ sulfonyl chloride ( $\mathrm{LRB}-\mathrm{SO}_{2} \mathrm{Cl}$ ), in the presence of $\mathrm{Et}_{3} \mathrm{~N}$ in $\mathrm{CH}_{2} \mathrm{Cl}_{2}$. The reaction yielded two fluorescent isomers, para-LRB-AC42 2a and orthoLRB-AC42 2b (Scheme 1), which were isolated by preparative reverse-phase high-performance liquid chromatography (RPHPLC). The two regioisomers were unambiguously characterized by ${ }^{1} \mathrm{H}$ NMR. Indeed, in agreement with previous reports on the identification of $\mathrm{LRB}$ isomers, ${ }^{36,37}$ the $\mathrm{H} 5$ proton of the lissamine moiety (Scheme 1) in ortho-LRB-AC42 is downfield the corresponding one in para-LRB-AC42 (8.02 ppm versus $7.92 \mathrm{ppm}$, respectively). The synthesis of paraLRB- $n$-butyl 20 followed the same procedure, starting from the $n$-butylamine (Scheme 5). The para isomer was isolated by RPHPLC as the major product of the reaction. Purity and identity of the compounds were checked by analytical RP-HPLC, liquid chromatography-mass spectrometry (LC-MS), and highresolution mass spectrometry (HRMS).

Altogether, the synthetic route we developed for $\mathrm{AC} 42-\mathrm{NH}_{2}$ led to the exchange of the AC-42 butyl chain for an aminopentyl one and subsequently to the introduction of a more flexible five-carbon atom linker between the AC-42 piperidine ring and the sulfonamide group of the fluorescent AC-42 derivatives.

Spectroscopic Characterization and Solubility Measurements. Spectroscopic properties of the fluorescent derivatives were examined in $\mathrm{MeOH}$ and Hepes buffer (Table 1). Their absorbance and fluorescence spectra are 
Scheme 5. Para-LRB-n-butyl 20 Preparation $^{a}$

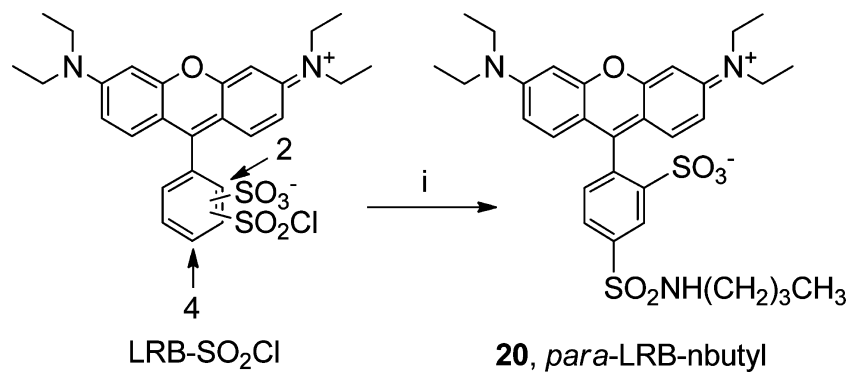

${ }^{a}$ Reagents: $n$-butylamine, $\mathrm{Et}_{3} \mathrm{~N}, \mathrm{CH}_{2} \mathrm{Cl}_{2}$, rt, overnight.

moderately sensitive to the environment or to chemical derivatization. In aqueous buffer, the ortho and para LRB conjugates display superimposable spectra but their molecular extinction coefficients are lower than in $\mathrm{MeOH}$. The three LRB derivatives are endowed with appropriate spectroscopic properties for an energy acceptor from excited EGFP (Supporting Information Figure S1): they display negligible absorbance at EGFP's excitation wavelength (set at $470 \mathrm{~nm}$ ), negligible emission at EGFP's emission wavelength (set at $510 \mathrm{~nm}$ ), appreciable overlap of their absorbance spectra with EGFP's emission spectrum, and large molecular extinction coefficients. The last properties dictate a substantial spectral overlap integral with EGFP and a great Förster radius $\left(R_{0}\right)$ for the para-LRB- $n$ butyl and para-LRB-AC42 compounds (Supporting Information Procedures). As expected for molecules bearing the same fluorophore, the para-LRB-derivatives share overall spectroscopic and acceptor properties with RR(17)PZ. ${ }^{38}$ This FRET tracer for $\mathrm{M} 1$ receptors was obtained through coupling of the succinimidyl ester of the Rhodamine Red-X fluorophore to functionalized pirenzepine, an M1 selective antagonist.

Ortho-LRB-AC42 was found to photofade in Hepes buffer to variable extent depending on the dilution factor of DMSO stock solutions. This precluded robust determination of its molecular extinction coefficient and $R_{0}$ (Table 1 , values in parentheses) and prompted us to evaluate the solubility limits of all fluorescent derivatives in aqueous buffer through quantitative HPLC analysis (Supporting Information Procedures). AC-42 and AC42- $\mathrm{NH}_{2}$ are perfectly soluble at $100 \mu \mathrm{M}$, as is para-LRB-AC42 at concentrations up to $30 \mu \mathrm{M}$. In contrast, para-LRB- $n$-butyl and surprisingly ortho-LRB-AC42 are much less soluble in Hepes buffer and begin to precipitate at concentrations beyond $2 \mu \mathrm{M}$. One should emphasize that solubility measurements were carried out without cells or BSA which may both act as ligand solubilizers. Thus, the solubilities listed above refer to bottom estimates for compound solubility.

Integrity of the M1 Receptor N-Terminus and AC-42 Agonism. We have already shown that shortening the human M1 muscarinic receptor N-tail, and its subsequent fusion to EGFP, does not alter receptor pharmacology or functionality but markedly improves energy transfer efficacy arising from binding of a fluorescent antagonist. ${ }^{27}$ Because previous mutagenesis studies proposed indirect evidence for AC-42 to bind to an ectopic site, involving the M1 receptor $\mathrm{N}$ terminus, ${ }^{10}$ we wondered whether such fluorescent receptors would be appropriate for studying the properties of AC-42 derivatives. To this end, we selected constructs with EGFP fused to a full length receptor (EGFP-wthM1) or to receptors truncated by $11(\operatorname{EGFP}(\Delta 11) \mathrm{hM} 1)$ or $17(\operatorname{EGFP}(\Delta 17) \mathrm{hM} 1)$ residues at their $\mathrm{N}$-terminus. The three fluorescent chimera, together with the wild-type hM1 receptor taken as a control, were stably expressed in HEK cells and tested for global $\left(\left[{ }^{3} \mathrm{H}\right] \mathrm{QNB}\right.$ binding) or cell surface $\left(\left[{ }^{3} \mathrm{H}\right] \mathrm{NMS}\right.$ binding $)$ receptor expression and for agonist-evoked calcium responses. AC-42 was found to stimulate all these receptors with comparable $\mathrm{EC}_{50}$ values (Table 2). Although subtle differences may rely on variations in receptor density, potencies are within the range of values reported for AC-42 $(0.15-1.8 \mu \mathrm{M}$, depending on cells lines and functional tests) at the wild-type M1 receptor. ${ }^{10,12,13,15,19,23,26}$ In line with these studies, AC-42 exhibits partial agonism at all receptor constructs (compared to carbachol) and shows no detectable activity (even at $10 \mu \mathrm{M}$ ) in nontransfected HEK cells with endogenous expression of the M3 subtype.

Thus, our data markedly contrast with previous conclusions based on the observation of altered AC-42 functionality following replacement of the first 45 amino acids of the M1 receptor with an equivalent M5 sequence. ${ }^{10}$ Note that a major part of the M1 first transmembrane domain was exchanged in this M1/M5 chimera. As neither the fusion of EGFP nor the deletion of the $\mathrm{M} 1$ receptor $\mathrm{N}$-terminus was detrimental to $\mathrm{AC}$ 42 agonist properties, the $\operatorname{EGFP}(\Delta 17) \mathrm{hM} 1$ construct was selected for all subsequent experiments.

Functional Properties of AC-42 Derivatives. We next examined the functional impact of the introduction of an aminomethyl group onto the AC-42 butyl chain (such as in AC42- $\mathrm{NH}_{2}$ ) and of its derivation by a bulky fluorophore (such as in para- and ortho-LRB-AC42). These compounds are no longer capable (when tested at 20 or at $37^{\circ} \mathrm{C}$ ) of promoting a calcium response in EGFP-wthM1 and $\operatorname{EGFP}(\Delta 17) \mathrm{hM} 1$ expressing cells or in nontransfected HEK cells. Instead, para-

Table 2. Functional Parameters for AC-42 in HEK Cells with Stable Expression of Wild Type or EGFP-Fused hM1 Receptors

\begin{tabular}{|c|c|c|c|c|c|}
\hline \multirow[b]{2}{*}{ receptor construct } & \multirow[b]{2}{*}{$\mathrm{N}$ tail length ${ }^{a}$ (residues) } & \multicolumn{2}{|c|}{ receptor expression ${ }^{b}\left(\mathrm{fmol} / 10^{6}\right.$ cells $)$} & \multicolumn{2}{|c|}{ calcium response ${ }^{c}$} \\
\hline & & {$\left[{ }^{3} \mathrm{H}\right] \mathrm{QNB}$} & {$\left[{ }^{3} \mathrm{H}\right] \mathrm{NMS}$} & $\mathrm{EC}_{50}(\mu \mathrm{M})$ & $E_{\max }(\%)$ \\
\hline none (HEK cells) & & $7 \pm 2$ & $5 \pm 2$ & NR & \\
\hline wthM1 & 21 & $262 \pm 25$ & $195 \pm 37$ & $0.74 \pm 0.03$ & $72 \pm 4$ \\
\hline EGFP-wthM1 & 20 & $940 \pm 50$ & nd & $0.21 \pm 0.08$ & $58 \pm 3$ \\
\hline $\operatorname{EGFP}(\Delta 11) \mathrm{hM} 1$ & 9 & $585 \pm 65$ & nd & $0.72 \pm 0.16$ & $57 \pm 4$ \\
\hline $\operatorname{EGFP}(\Delta 17) \mathrm{hM} 1$ & 3 & $710 \pm 44$ & $690 \pm 40$ & $0.45 \pm 0.08$ & $67 \pm 7$ \\
\hline
\end{tabular}

${ }^{a}$ The length of the $\mathrm{N}$ terminus (number of residues) of the wild-type hM1 receptor and of the various constructs is indicated. ${ }^{b}$ Receptor expression levels (mean \pm SE values for three independent determinations) are from $\left[{ }^{3} \mathrm{H}\right] \mathrm{QNB}$ and $\left[{ }^{3} \mathrm{H}\right] \mathrm{NMS}$ binding assays conducted on intact cells at saturating radioligand concentrations. n.d., not determined. ${ }^{c}$ Measurements of AC- 42 evoked calcium responses allowed the determination (mean \pm $\mathrm{SD}$ values from two separate determinations) of $\mathrm{EC}_{50}$ and $E_{\max }$ (normalized relative to the maximum response of cells to $10 \mu \mathrm{M}$ carbachol) parameters. NR: no response. 
LRB-AC42 and AC42- $\mathrm{NH}_{2}$ fully abolish (Figure 3), in a dosedependent manner $\left(\mathrm{IC}_{50}\right.$ values of $0.3 \pm 0.1$ and $3.7 \pm 1.4 \mu \mathrm{M}$,

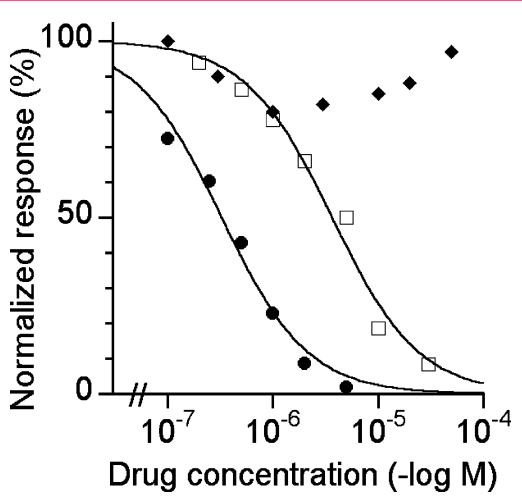

Figure 3. Inhibition by $\mathrm{AC}-42$ derivatives of carbachol-induced calcium responses in $\operatorname{EGFP}(\Delta 17) \mathrm{hM} 1$ cells. Response amplitudes are expressed as percentages of a control response to $0.5 \mu \mathrm{M}$ carbachol and are plotted as a function of para-LRB-AC42 $(\bullet), \mathrm{AC}^{-}-\mathrm{NH}_{2}(\square)$ and ortho-LRB-AC42 $(\checkmark)$ concentration. This typical experiment was performed at $20^{\circ} \mathrm{C}$ as reported in the Experimental Section.

respectively; $n=2)$, the robust $\mathrm{M} 1$ response elicited by $0.5 \mu \mathrm{M}$ carbachol $\left(\mathrm{EC}_{50}\right.$ of $\left.0.25 \mu \mathrm{M}\right)$ in $\operatorname{EGFP}(\Delta 17) \mathrm{hM} 1$ cells. Blockade by ortho-LRB-AC42 is partial, with a $20 \%$ maximal inhibition at $1 \mu \mathrm{M}$ that progressively vanishes at higher doses. Such a behavior is most probably related to the poor solubility of this derivative. The $\mathrm{LRB}-\mathrm{SO}_{3}{ }^{-} \mathrm{Na}^{+}$fluorophore was inactive at $1 \mathrm{mM}$ (not shown).

The calcium response elicited by $0.5 \mu \mathrm{M}$ carbachol in $\operatorname{EGFP}(\Delta 17) \mathrm{hM} 1$ cells is essentially $\mathrm{M} 1$ in nature, as activation of endogenous M3 receptors in nontransfected HEK cells requires much higher carbachol $\left(\mathrm{EC}_{50}\right.$ close to $\left.15 \mu \mathrm{M}\right)$ concentrations. ${ }^{39}$ As neither para-LRB-AC42 nor $\mathrm{AC} 42-\mathrm{NH}_{2}$ is able to inhibit (even at $10 \mu \mathrm{M}$ ) the strong $\mathrm{M} 3$ calcium response elicited by $20 \mu \mathrm{M}$ carbachol in HEK cells, one may conclude that these AC- 42 derivatives still exhibit a M1 over M3 selective functional antagonism.

$\left[{ }^{3} \mathrm{H}\right]$ NMS Inhibition Binding Studies at EGFP( $(\Delta 17) \mathrm{hM} 1$

Receptors. The properties of $\mathrm{AC} 42-\mathrm{NH}_{2}$ and of the LRB family of compounds were further examined through equilibrium binding experiments, using $\left[{ }^{3} \mathrm{H}\right] \mathrm{NMS}$ as the orthosteric site probe. Incubation of $\operatorname{EGFP}(\Delta 17) \mathrm{hM} 1$ cells proceeded in physiological Hepes buffer at $20^{\circ} \mathrm{C}$ in order to minimize receptor and ligand internalization and for $22 \mathrm{~h}$ to ensure equilibrium in the presence of allosteric ligands. ${ }^{40}$ The apparent equilibrium dissociation constant $(95 \pm 7 \mathrm{pM}$, mean \pm SE; $n=8)$ for specific $\left[{ }^{3} \mathrm{H}\right] \mathrm{NMS}$ binding to $\operatorname{EGFP}(\Delta 17)$ hM1 cells coincided well with $K_{d}$ values reported for this radiotracer on M1-enriched membrane preparations. ${ }^{40-42}$ Displacement experiments (Figure 4) were usually performed at two radioligand concentrations (about $1 K_{\mathrm{d}}$ and $10 K_{\mathrm{d}}$ ) in order to better distinguish competitive from negatively cooperative modes of interaction. ${ }^{4,6}$ Slope factors for all inhibition curves did not statistically differ from 1. Binding parameters are listed in Table 3.

As shown in Figure 4A, atropine fully displaces specific $\left[{ }^{3} \mathrm{H}\right] \mathrm{NMS}$ binding at low and high tracer concentrations, as expected for competition at the orthosteric receptor site. $\mathrm{N}$ desmethylclozapine exhibits a similar competitive-like behavior and $K_{\mathrm{i}}$ in full agreement with published data. ${ }^{9,12,23}$

The allosteric modulator gallamine displays a typical submaximal inhibition (with plateau levels depending on $\left[{ }^{3} \mathrm{H}\right] \mathrm{NMS}$ concentration) consistent with a saturable and negatively cooperative mode of interaction. Analysis according to the allosteric ternary complex model ${ }^{8}$ yielded estimates of gallamine equilibrium dissociation constant $K_{x}$ for the classical allosteric site on free M1 receptors and of the cooperativity factor $\alpha$ as a measure of its impact on $\left[{ }^{3} \mathrm{H}\right] \mathrm{NMS}$ binding affinity (Table 3 ). Both parameters are in good agreement with previous reports on M1 membrane preparations, ${ }^{11,42,43}$ as are those determined here for brucine (Table 3), another allosteric modulator. ${ }^{44,45}$

AC-42 displays an apparent competitive mode of interaction (Figure 4B) and an affinity constant (Table 3) in close agreement with previous reports. ${ }^{20,23,24}$ Interestingly, such properties are shared by $\mathrm{AC} 42-\mathrm{NH}_{2}$. The introduction of a butyl chain onto the almost inactive $\mathrm{LRB}-\mathrm{SO}_{3}{ }^{-} \mathrm{Na}^{+}$fluorophore confers to para-LRB- $n$-butyl the ability to inhibit, though partially, $\left[{ }^{3} \mathrm{H}\right] \mathrm{NMS}$ binding in the micromolar concentration range. Similar features, mirroring negative binding cooperativity with $\left[{ }^{3} \mathrm{H}\right] \mathrm{NMS}$, apply to ortho-LRB-AC42 (Figure 4C). Unfortunately, given their poor solubility in physiological Hepes buffer, it was impossible to define the exact nature of their interaction with M1 receptors or to provide reasonable estimates of their binding parameters. Most importantly, however, as shown in Figure 4C, the para-LRB-AC42 derivative
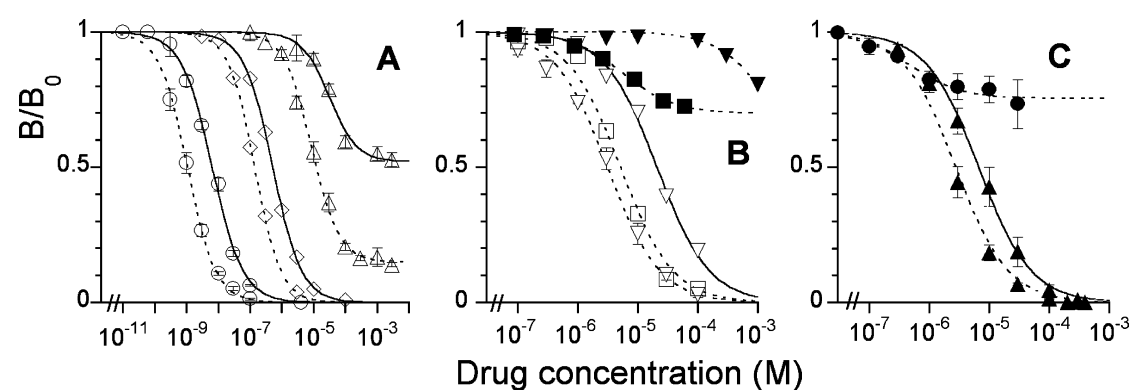

Figure 4. Inhibition of $\left[{ }^{3} \mathrm{H}\right] \mathrm{NMS}$ binding to $\operatorname{EGFP}(\Delta 17) \mathrm{hM} 1$ receptors by orthosteric and allosteric compounds, AC-42, and lissamine rhodamine $\mathrm{B}$ derivatives. Competition-type experiments were performed at low $\left(80-110 \mathrm{pM}\right.$; dashed lines) and high $\left(800-950 \mathrm{pM}\right.$; solid lines) [ $\left.{ }^{3} \mathrm{H}\right]-\mathrm{NMS}$ concentrations in the absence $\left(\mathrm{B}_{0}\right.$ value) or the presence (B values) of unlabelled (open symbols) or fluorescent (closed symbols) drugs. A: Atropine $\mathrm{O}, \mathrm{NDMC} \diamond$, gallamine $\triangle$; B: AC-42 $\nabla$, AC42- $\mathrm{NH}_{2} \square$, para-LRB-nbutyl $\mathbf{\square}$, LRB-SO ${ }_{3}{ }^{-} \mathrm{Na}^{+} \boldsymbol{\nabla}$; C: para-LRB-AC42 $\boldsymbol{\Delta}$, ortho-LRB-AC42 $\bullet$. Data are presented as $\mathrm{B} / \mathrm{B}_{0}$ ratios (mean $\pm \mathrm{SE}$ values for three to eight separate experiments). Error bars are shown when they exceed the symbols. Curve fitting was carried out using the standard Hill equation with the exception of gallamine data which were analysed according to the allosteric ternary complex model (Supplemental Procedures). Corresponding parameters are listed in Table 3. 
Table 3. Binding Parameters for a Series of Compounds at $\operatorname{EGFP}(\Delta 17) \mathrm{hM1}$ Receptors As Afforded from Equilibrium and OffRate $\left[{ }^{3} \mathrm{H}\right]$ NMS Binding Assays ${ }^{a}$

\begin{tabular}{|c|c|c|c|c|c|}
\hline \multirow[b]{2}{*}{ compd } & \multicolumn{3}{|c|}{ equilibrium assay $^{b}$} & \multicolumn{2}{|c|}{ off-rate assay $^{c}$} \\
\hline & $\mathrm{p} K_{\mathrm{i}}$ & $\mathrm{p} K_{x}$ & $\log \alpha$ & $\mathrm{pEC}_{50 \text { diss }}$ & $E_{\text {max,diss }}$ \\
\hline NMS & $10.02 \pm 0.04^{d}$ & & & & \\
\hline atropine & $9.24 \pm 0.04$ & & & & \\
\hline gallamine & & $5.30 \pm 0.04$ & $1.10 \pm 0.05$ & $3.76 \pm 0.02$ & $100 \pm 5$ \\
\hline brucine & & $4.59 \pm 0.01$ & $0.10 \pm 0.02$ & nd & \\
\hline$N$-desmethylclozapine & $7.22 \pm 0.05$ & & & nd & \\
\hline AC-42 & $5.76 \pm 0.07$ & & & nd & \\
\hline $\mathrm{AC} 42-\mathrm{NH}_{2}$ & $5.71 \pm 0.06$ & & & nd & \\
\hline para-LRB-AC42 & $6.00 \pm 0.08$ & & & $\begin{array}{l}4.6 \pm 0.1 \\
(4.4 \pm 0.1)^{e}\end{array}$ & $\begin{array}{l}79 \pm 5 \\
(100)^{e}\end{array}$ \\
\hline $\mathrm{LRB}-\mathrm{SO}_{3}{ }^{-} \mathrm{Na}^{+}$ & $<3$ & & & nd & \\
\hline
\end{tabular}

${ }^{a}$ Data are the mean \pm SE values for three to nine independent experiments performed in duplicate as described in Experimental Section. Data analyses are detailed in Supporting Information Procedures. ${ }^{b}$ Equilibrium dissociation constants $(-\log M)$ for the binding of competitive-like (orthosteric, $K_{\mathrm{i}}$ values) and noncompetitive (allosteric, $K_{x}$ values) compounds to free receptors are indicated together with the cooperativity factor $(\alpha)$ governing the allosteric interaction between a modulator and $\left[{ }^{3} \mathrm{H}\right] \mathrm{NMS}$. ${ }^{c} \mathrm{pEC}_{50 \text { diss }}$ refers to the drug concentration $(-\log M)$ that induces halfmaximal reduction of control $\left[{ }^{3} \mathrm{H}\right] \mathrm{NMS}$ dissociation rate. $E_{\text {max,diss }}$ defines the maximal extent (\%) of inhibition of $\left[{ }^{3} \mathrm{H}\right] \mathrm{NMS}$ dissociation rate. nd: not determined. ${ }^{d} K_{\mathrm{d}}$ value from $\left[{ }^{3} \mathrm{H}\right] \mathrm{NMS}$ saturation experiments. ${ }^{e}$ Parameters are from Figure $5 \mathrm{~B}$ with constrained curve fitting.

(which is not hampered by such solubility limitations) fully displaces specific $\left[{ }^{3} \mathrm{H}\right] \mathrm{NMS}$ binding from the $\operatorname{EGFP}(\Delta 17) \mathrm{hM} 1$ receptor at low and high tracer concentrations.

Special attention was then paid to the mode of interaction of AC-42, AC42- $\mathrm{NH}_{2}$, para-LRB-AC42, and NDMC, which all inhibited $\left[{ }^{3} \mathrm{H}\right] \mathrm{NMS}$ binding down to nonspecific levels. All our attempts to distinguish strict competition from strong negative cooperativity, such as the comparison of inhibition levels at low and high tracer concentrations, the use of individual versus global curve fitting to both models, or the statistical examination of model relevance, unfortunately failed. For example, the increase in $\left[{ }^{3} \mathrm{H}\right] \mathrm{NMS}$ concentration (Figure $4 \mathrm{C}$ ) resulted in a rightward shift of the $\mathrm{IC}_{50}$ value for para-LRBAC42 that is about 2-fold lower than that predicted for a competitive interplay. Such an observation might be interpreted as the manifestation of a ceiling effect on inhibition magnitude, reflecting negative binding cooperativity between $\left[{ }^{3} \mathrm{H}\right] \mathrm{NMS}$ and the fluorescent compound. ${ }^{6,8}$ In turn, the competitive model was preferred over the allosteric one when submitting para-RR-AC42 curve pairs to a global fitting procedure. Moreover, while some equilibrium binding studies pointed to an allosteric behavior of AC-42, ${ }^{11,12}$ recent reports indicate the competitive model as the most reasonable one to interpret $\mathrm{AC}$ $42^{23,24}$ and $\mathrm{NDMC}^{12,23}$ equilibrium binding data. Accordingly, we assumed AC-42, AC42-NH $\mathrm{N}_{2}$, para-LRB-AC42, and NDMC interactions with the $\operatorname{EGFP}(\Delta 17) \mathrm{hM} 1$ receptor to be competitive-like and provide their $\mathrm{K}_{\mathrm{i}}$ values in Table 3 .

$\left[{ }^{3} \mathrm{H}\right]$ NMS Dissociation Kinetic Studies. Examination of $\left[{ }^{3} \mathrm{H}\right] \mathrm{NMS}$ dissociation kinetics is regarded as a stringent test to detect an allosteric modulation of mAChRs. ${ }^{40,46}$ Indeed, the binding of allosteric ligands causes conformational changes in the receptor, most often manifested as an alteration in off-rate kinetics of preformed orthosteric ligand-receptor complexes. Such studies were thus undertaken to get further information on the binding nature of the AC-42 derivatives.

Figure 5A allows comparison of the ability of several compounds (taken at $100 \mu \mathrm{M}$ ) to alter the $\left[{ }^{3} \mathrm{H}\right] \mathrm{NMS}$ dissociation rate from $\operatorname{EGFP}(\Delta 17) \mathrm{hM} 1$ receptors. Atropine $(10 \mu \mathrm{M})$ was systematically included in the assays to prevent $\left[{ }^{3} \mathrm{H}\right]$ NMS reassociation to the orthosteric site. The control (atropine alone, $k_{\text {off control }}=0.044 \pm 0.001 \mathrm{~min}^{-1} ; n=4$ ) and all other dissociation traces fit a single exponential time course. The para-LRB-AC42 $\left(k_{\text {off obs }}=0.013 \pm 0.001 \mathrm{~min}^{-1}\right)$ and AC42- $\mathrm{NH}_{2}\left(\mathrm{k}_{\text {off obs }}=0.028 \pm 0.001 \mathrm{~min}^{-1}\right)$ compounds significantly slow $\left[{ }^{3} \mathrm{H}\right] \mathrm{NMS}$ dissociation, while ortho-LRB$\mathrm{AC} 42\left(k_{\text {off obs }}=0.041 \pm 0.002 \mathrm{~min}^{-1}\right)$ and para-LRB- $n$-butyl (not shown) effects are not significant (mean \pm SD values, $n=$ 2).

Figure 5B depicts the concentration dependence of the retardation effects of the allosteric modulator gallamine and of para-LRB-AC42 on $\left[{ }^{3} \mathrm{H}\right] \mathrm{NMS}$ dissociation from $\operatorname{EGFP}(\Delta 17)$ hM1 receptors. In agreement with previous reports, ${ }^{40,42}$ gallamine completely blocks $\left[{ }^{3} \mathrm{H}\right] \mathrm{NMS}$ dissociation from the receptor $\left(E_{\max }=100 \%\right)$, with an $\mathrm{EC}_{50}$ diss close to $170 \mu \mathrm{M}$ reflecting its affinity for $\left[{ }^{3} \mathrm{H}\right] \mathrm{NMS}$-occupied receptors (Table 3). Para-LRB-AC42 data also satisfactorily fit an inhibition curve with a slope close to unity, but reduction of $\left[{ }^{3} \mathrm{H}\right] \mathrm{NMS}$ dissociation rate is limited $\left(E_{\max }=80 \%\right)$ with half-maximal retardation at $25 \mu \mathrm{M}$ (Table 3 ). To our knowledge, such dosedependency studies have not been reported yet for AC-42 probably because it combines a modest effect on $\left[{ }^{3} \mathrm{H}\right] \mathrm{NMS}$ dissociation rate and a limited solubility at high concentrations. ${ }^{12,20,24}$ Taking this factor as a valid reason for the inability of para-LRB-AC42 to fully prevent $\left[{ }^{3} \mathrm{H}\right] \mathrm{NMS}$ dissociation at concentrations above $100 \mu \mathrm{M}$, data were reanalyzed (Figure 5B, dashed line), focusing on a $1-50 \mu \mathrm{M}$ window with $E_{\max }$ and slope values constrained to $100 \%$ and $1 \%$, respectively. The nominal $100 \mu \mathrm{M}$ para-LRB-AC42 concentration was found to correspond to $50 \mu \mathrm{M}$ freely diffusing molecules in Hepes buffer (HPLC solubility measurements). A slightly higher $\mathrm{EC}_{50}$ diss $(40 \mu \mathrm{M})$ was then determined.

Altogether and in contrast with equilibrium studies, the kinetic data support the idea that $A C 42-\mathrm{NH}_{2}$ and para-LRBAC42 bind to an allosteric site on $\left[{ }^{3} \mathrm{H}\right] \mathrm{NMS}$-occupied M1 receptors, as do AC-42 $2^{11,12,24}$ and $77-\mathrm{LH}-28-1^{24}$ molecules.

Toward FRET Recordings of Para-LRB-AC42 Binding to EGFP $(\Delta 17) \mathrm{hM} 1$ Receptors. Figure 6A illustrates a FRET experiment performed at $20{ }^{\circ} \mathrm{C}$ on HEK cells expressing the $\operatorname{EGFP}(\Delta 17) \mathrm{hM1}$ receptor, using para-LRB-AC42 as the fluorescent tracer, with real-time recordings of EGFP fluorescence emission at $510 \mathrm{~nm}$. Upon ligand addition (a, 5 

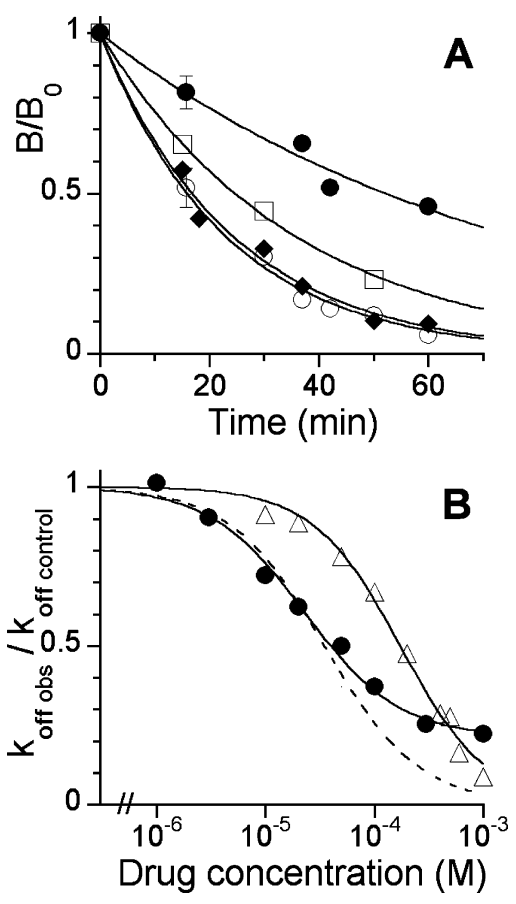

Figure 5. Effect of AC-42 derivatives on $\left[{ }^{3} \mathrm{H}\right] \mathrm{NMS}$ dissociation rate. Measurement of $\left[{ }^{3} \mathrm{H}\right]$-NMS dissociation rate from $\operatorname{EGFP}(\Delta 17) \mathrm{hM} 1$ receptors was carried out at $25{ }^{\circ} \mathrm{C}$ as described in the Experimental Section. A: Dissociation started with the addition of $10 \mu \mathrm{M}$ atropine alone (O) or combined with $100 \mu \mathrm{M}$ of either $\mathrm{AC} 42-\mathrm{NH}_{2}(\square)$, orthoLRB-AC42 $(\diamond)$ or para-LRB-AC42 $(\bullet)$. Specific $\left[{ }^{3} \mathrm{H}\right]$-NMS binding (B value) remaining at various dissociation time points is normalized to initial binding $\left(\mathrm{B}_{0}\right.$ value $)$ at time $0 . \mathrm{B} / \mathrm{B}_{0}$ ratios are mean $\pm S D$ values for two to four independent experiments. Best fits to a monoexponential decay are shown (Supplemental Procedures). B: Concentration-effect curves are plotted from $\left[{ }^{3} \mathrm{H}\right]$-NMS dissociation studies performed in the presence of $10 \mu \mathrm{M}$ atropine and of increasing concentrations of gallamine $(\triangle)$ or para-LRB-AC42 $(\bullet)$. Observed dissociation rates $\left(k_{\text {off obs }}\right)$ are normalized to control rates $\left(k_{\text {off control }}\right)$ measured with atropine alone. Data are mean \pm SD values for three independent experiments. Curve fitting to the Hill equation provided $\mathrm{EC}_{50 \text { diss }}$ and $E_{\max \text { diss }}$ parameters (Table 3). When selecting a 1-50 $\mu \mathrm{M}$ para-LRB-AC42 concentration window, curve fitting proceeded with maximal amplitude and slope constrained to 1 (dashed line).

$\mu \mathrm{M})$ to the cell suspension, fluorescence decreases almost instantaneously to a plateau value featuring stable binding equilibrium. Subsequent addition of AC-42 (b, $30 \mu \mathrm{M})$ induces a fast fluorescence recovery, indicative of para-LRB-AC42 dissociation, reaching a level that exceeds that achieved when using atropine $(20 \mu \mathrm{M})$. A key observation was the measurement of an identical increment of fluorescence when adding AC-42 to naive (c) or atropine-treated (d) cells. The origin of such an artifact remains unclear. It is reproduced well with AC42- $\mathrm{NH}_{2}$ and exhibits a strict concentration dependency (Figure 6B inset), is independent of the nature and the expression levels of EGFP-fused receptors, is related somehow to HEK cell constituents, and is negligible in Hepes buffer. As a consequence, $\mathrm{AC}-42$ and $\mathrm{AC} 42-\mathrm{NH}_{2}$ cannot be taken as safe compounds to validate the receptor specificity of FRET signals, under equilibrium or kinetic conditions.

Another point highlighted in Figure $6 \mathrm{~A}$ is the apparent discrepancy between the amplitudes of fluorescence extinction at equilibrium and of fluorescence recovery upon addition of atropine. A series of controls, performed with Hepes buffer or nontransfected HEK cells, indicate that actual fluorescence extinction is minored by a para-LRB-AC42 emission component. Although para-LRB-AC42 displays (Supporting Information Figure S1) negligible absorbance and emission at EGFP's excitation $(470 \mathrm{~nm})$ and emission $(510 \mathrm{~nm})$ wavelengths, respectively, direct excitation at $470 \mathrm{~nm}$ of micromolar amounts of tracer leads to significant emission at $510 \mathrm{~nm}$. After correction of this interference, which is proportional to the para-LRB-AC42 concentration, fluorescence extinction and fluorescence recovery now define an identical FRET signal amplitude.

In summary, specific para-LRB-AC42 binding to the $\operatorname{EGFP}(\Delta 17) \mathrm{hM} 1$ receptor was defined, under equilibrium binding conditions, as the difference in fluorescence intensity of cells incubated with the tracer, in the presence or the absence of a saturating concentration of atropine, or under kinetic conditions, as the amplitude of atropine-promoted fluorescence recovery. Such FRET signals are not detected on HEK cells stably expressing non-M1 EGFP-fused GPCRs or with pure soluble EGFP, thereby confirming their muscarinic receptor specificity.

Despite the problems listed above, AC-42 and AC42- $\mathrm{NH}_{2}$ are pivotal compounds that need to be included in the present FRET study to help characterize fluorescent tracer properties. The procedure we developed to afford a safe determination of their binding parameters is illustrated with $\mathrm{AC} 42-\mathrm{NH}_{2}$ (Figure $6 \mathrm{~B})$. First, the amplitude of the artifact resulting from its addition to $\operatorname{EGFP}(\Delta 17) \mathrm{hM} 1$ cells (or to HEK cells) was found to be proportional to its concentration (Figure $6 \mathrm{~B}$ inset). Second, competition-type studies were performed using paraLRB-AC42 $(5 \mu \mathrm{M})$ and increasing concentrations of the AC-42 analogue. They are presented as occupancy curves, with 0 and 100 referring to fluorescence levels of $\operatorname{EGFP}(\Delta 17) \mathrm{hM} 1$ cells incubated with the tracer, in the absence or presence of $20 \mu \mathrm{M}$ atropine, respectively. As shown in Figure 6B, fluorescence recovery versus $\mathrm{AC} 42-\mathrm{NH}_{2}$ concentration appears as a nonsaturable process and clearly exceeds the atropine-defined specific FRET signal amplitude. Fitting these raw data according to the Hill equation superimposed with a linear drift accounting for $\mathrm{AC} 42-\mathrm{NH}_{2}$ artifact allowed extraction of a typical occupancy curve with a slope close to 1 , half-maximal occupation (equivalent to an $\mathrm{IC}_{50}$ ) at $10 \pm 1 \mu \mathrm{M}$, and a maximal amplitude $(102 \pm 3 \%)$ nonsignificantly different from $100 \%$. Finally, very similar parameters were determined after correction of each raw data point for the fluorescent artifact measured at the same AC42- $\mathrm{NH}_{2}$ concentration on naive cells (Figure 5B inset). The latter procedure was used routinely to quantify and correct undesirable fluorescence artifacts due to some chemicals.

Association and dissociation kinetics for para-LRB-AC42 binding to $\operatorname{EGFP}(\Delta 17) \mathrm{hM} 1$ cells are very fast (Figure $6 \mathrm{~A}$ ). This enabled us to monitor, over $50 \mathrm{~s}$ periods of time, the impact on cell fluorescence of the addition of cumulative doses of tracer (Figure 6C). The concentration-dependent fluorescence extinction (with ligand emission artifact visible at high tracer concentration) was fully prevented by cell preincubation with atropine $(20 \mu \mathrm{M})$. Specific para-LRB-AC42 binding, as defined by the difference in fluorescence levels between both assays, reaches a maximum at $3 \mu \mathrm{M}$ tracer, featuring a saturable process.

Finally and to further confirm the muscarinic specificity of the FRET signal associated with para-LRB-AC42 binding, the experiment was repeated using propylbenzilylcholine mustard (PrBCM) to selectively alkylate the Asp105 (3.32) receptor 

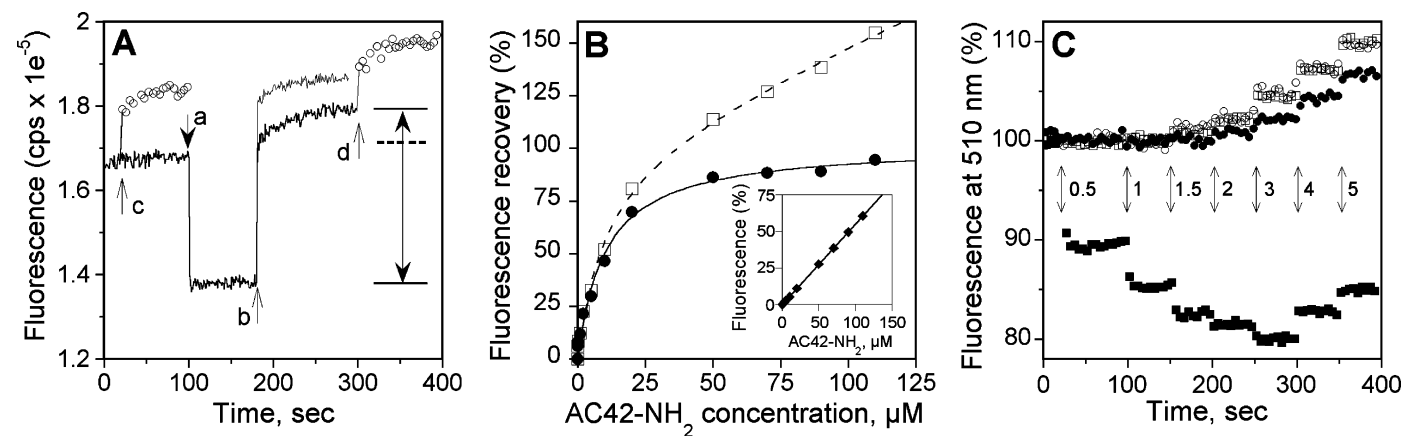

Figure 6. Definition of the specificity of FRET signals associated with para-LRB-AC42 binding to $\operatorname{EGFP}(\Delta 17) \mathrm{hM} 1$ receptors. A: Real-time monitoring of fluorescence variations (data sampled every $0.5 \mathrm{sec}$ ) of EGFP $(\Delta 17) \mathrm{hM} 1$ cells upon addition (arrow a) of $5 \mu \mathrm{M}$ para-LRB-AC42 and (arrow b) of either atropine $(20 \mu \mathrm{M}$; thick trace) or AC-42 $(30 \mu \mathrm{M}$; thin trace). Two other experiments $(\mathrm{O})$ point to a very similar artefactual increase in fluorescence $(16500 \mathrm{cps})$ following the addition of $30 \mu \mathrm{M} \mathrm{AC}-42$ to naive (arrow c) or para-LRB-AC42 and atropine-treated (arrow d) cells. Specific binding of para-LRB-AC42, as defined by the atropine-sensitive fluorescence recovery (double headed arrow), corresponds to a FRET signal with $24.5 \%$ extinction of cell fluorescence. After deduction of its artefact, AC-42 was found to displace up to $80 \%$ (---) of specific para-LRBAC42 binding. B: Validation of a competition experiment using AC42- $\mathrm{NH}_{2}$ and para-LRB-AC42 under FRET conditions. EGFP( $\left.\Delta 17\right) \mathrm{hM} 1$ expressing cells are incubated for $1 \mathrm{~h}$ at $20^{\circ} \mathrm{C}$ with $5 \mu \mathrm{M}$ para-LRB-AC42 in the absence or the presence of either atropine $(20 \mu \mathrm{M})$ or increasing concentrations of AC42- $\mathrm{NH}_{2}$. Fluorescence levels at equilibrium are measured at $510 \mathrm{~nm}$ as reported in the Experimental Section. The $\mathrm{AC}^{2}-\mathrm{NH}_{2}$ concentration-dependent increase in fluorescence $(\square)$ is normalized in percent to the amplitude for atropine-prevented fluorescence extinction (specific FRET signal; 100\%). Data fitting (--) to the Hill equation derived for saturation superimposed with a linear drift to account for $\mathrm{AC}_{42-\mathrm{NH}_{2}}$ artefact allowed to extract a typical inhibition curve $(\bullet)$ for para-LRB-AC42 binding, with an $\mathrm{IC}_{50}(\mu \mathrm{M})$ of $10.2 \pm 1.2$ and a maximal amplitude (\%) of $101.8 \pm 2.9$, and to define a slope $(0.55 \pm 0.1)$ for the linear drift (not shown). A parallel experiment (insert), performed on the same cells in the absence of para-LRB-AC42, provided a direct measurement of $\mathrm{AC} 42-\mathrm{NH}_{2}$ fluorescence artefact. Data are normalized as detailed above and fitted according to a linear relationship (slope factor $0.58 \pm 0.01)$. C: Receptor alkylation by PrBCM $(30 \mathrm{nM})$ and para-LRB-AC42 binding. Control ( $\mathbf{\square}$, $\square)$ or PrBCM-treated $(\bullet, \bigcirc$; Experimental Section) EGFP $(\Delta 17) \mathrm{hM} 1$ cells, taken at an identical density, were preincubated (open symbols) or not (black symbols) with $20 \mu \mathrm{M}$ atropine for $5 \mathrm{~min}$ at $20^{\circ} \mathrm{C}$. Thereafter, cell samples were examined for their ability to generate a FRET signal upon sequential addition (arrows) of cumulative doses of para-LRB-AC42 (final concentrations indicated in $\mu \mathrm{M}$ ). Fluorescence at $510 \mathrm{~nm}$ was monitored in real time ( 1 point per second; $20 \%$ of points are shown). Specific FRET signals (atropine-protected fluorescence extinction in \%) measured with 5 $\mu \mathrm{M}$ para-LRB-AC42 were respectively of 25 and 2.8 for control and PrBCM-treated cells, respectively.

residue. ${ }^{47}$ Indeed, this conserved amino acid plays a well-known critical role in the binding of orthosteric ligands to all aminergic GPCRs. ${ }^{48}$ Its mutation has also been shown to abolish signaling by novel muscarinic agonists such as AC-42, 77-LH-28-1, and NDMC. ${ }^{12,23}$ Upon treatment with PrBCM (30 nM), we found that $\operatorname{EGFP}(\Delta 17) \mathrm{hM} 1$ cells display a marked reduction (90$95 \%)$ in their ability to elicit a calcium response to AC-42 (10 $\mu \mathrm{M})$, to bind $\left[{ }^{3} \mathrm{H}\right] \mathrm{NMS}(0.7 \mathrm{nM})$, or to promote a FRET signal in the presence of the fluorescent pirenzepine derivative $\mathrm{RR}(17) \mathrm{PZ}^{38}$ at $200 \mathrm{nM}$. As shown in Figure 6C, M1 receptor alkylation by PrBCM also almost completely abolishes (up to $90 \%$ at saturating tracer concentrations) the atropine-sensitive FRET signal promoted by para-LRB-AC42 binding.

Equilibrium Binding Properties of Para-LRB-AC42 at $\operatorname{EGFP}(\Delta 17) \mathrm{hM} 1$ Receptors. Saturation experiments were performed on a $0.25-10 \mu \mathrm{M}$ concentration range of paraLRB-AC42 (Figure 7A). Essentially similar results were obtained whether $\operatorname{EGFP}(\Delta 17) \mathrm{hM} 1$ cells (preincubated or not for 5 min with $20 \mu \mathrm{M}$ atropine) were submitted to cumulative tracer addition and checked in real time for fluorescence levels at binding equilibrium (as in Figure 6C) or incubated for $4 \mathrm{~h}$ at $20{ }^{\circ} \mathrm{C}$ with increasing tracer concentrations in separate test tubes. Data fitting to the empirical Hill equation derived for saturation allowed the determination (mean \pm SE values, $n=5$ ) of the $K_{\mathrm{d}}(0.8 \pm 0.1 \mu \mathrm{M})$, maximal FRET amplitude $(26.5 \pm$ $1.4 \%)$, and slope factor $(1.06 \pm 0.08)$ for specific binding of para-LRB-AC42 to $\operatorname{EGFP}(\Delta 17) \mathrm{hM} 1$ receptors. Note that the $K_{\mathrm{d}}$ for the fluorescent tracer coincides well with its affinity estimated from $\left[{ }^{3} \mathrm{H}\right]$ NMS competition studies (Table 3), thereby confirming the validity of FRET measurements. Very low affinity $\mathrm{LRB}-\mathrm{SO}_{3}{ }^{-} \mathrm{Na}^{+}$binding was fitted according to a linear relationship with tracer concentration.

Assuming that cell surface receptors account for $90 \%$ to overall fluorescence of $\operatorname{EGFP}(\Delta 17) \mathrm{hM} 1$ cells (ratio of $B_{\max }$ values for $\left[{ }^{3} \mathrm{H}\right] \mathrm{NMS}$ and $\left[{ }^{3} \mathrm{H}\right] \mathrm{QNB}$ binding, Table 2$)$, maximal fluorescence extinction (27\%, measured at saturating para-LRBAC42 concentrations) may be converted into specific EGFP extinction (30\%) to provide the energy transfer efficacy $E$ (0.30). This enabled us to estimate the actual distance $R$ (59.2 $\pm 0.7 \AA$ ) separating EGFP from the LRB fluorophore of the tracer, using the $R=R_{0}(1 / E-1)^{1 / 6}$ Förster relationship ${ }^{49}$ and $R_{0}$ values listed in Table 1 (Supporting Information Procedures).

We finally focused on para-LRB-AC42 equilibrium binding properties through competition experiments (Figure 7B) performed on $\operatorname{EGFP}(\Delta 17) \mathrm{hM} 1$ cells using a set of wellknown orthosteric and allosteric muscarinic compounds. NMS, atropine, AC-42, and AC42- $\mathrm{NH}_{2}$ (not shown) all follow a competitive-like mode of interaction. The allosteric modulators gallamine and brucine (not shown) also fully inhibit specific para-LRB-AC42 binding at high concentrations. Interestingly, Win $51,708,{ }^{50}$ an allosteric modulator known to interact on M1 receptors at a site distinct from that of gallamine, and NDMC, ${ }^{12,23}$ an atypical allosteric agonist possibly overlapping the $\left[{ }^{3} \mathrm{H}\right] \mathrm{NMS}$ orthosteric binding domain, both exhibit weak negative binding cooperativity with para-LRB-AC42. The potent and M1 selective allosteric MT7 toxin $^{45}$ was totally inactive even at $10 \mathrm{nM}$ (not shown). Quantitative analysis of the data was done using appropriate sets of equations for competitive or cooperative interactions to define the parameters listed in Table 4 . The affinity constants of drugs 

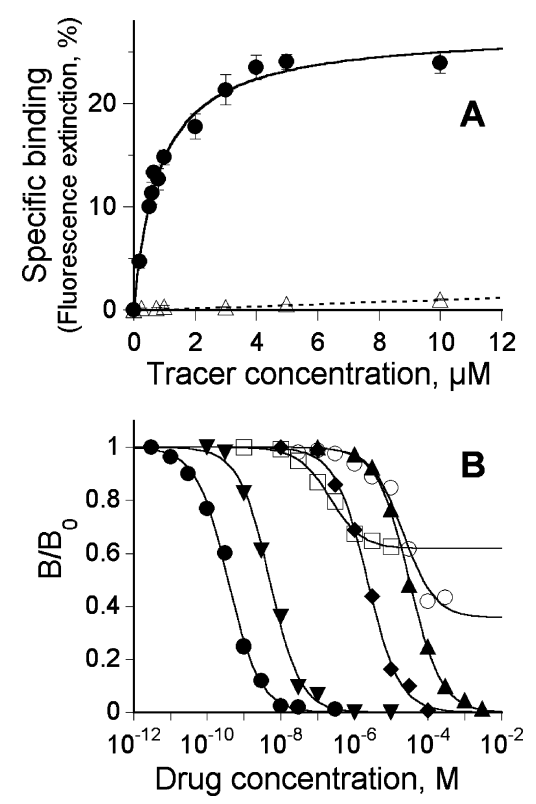

Figure 7. Binding properties of fluorescent tracers and of a series of muscarinic compounds at $\operatorname{EGFP}(\Delta 17) \mathrm{hM} 1$ receptors as monitored by FRET experiments. A: $\operatorname{EGFP}(\Delta 17) \mathrm{hM} 1$ cells were incubated at $20^{\circ} \mathrm{C}$ for $4 \mathrm{~h}$ with increasing concentrations of para-LRB-AC42 (-) or LRB$\mathrm{SO}_{3}{ }^{-} \mathrm{Na}^{+}(\triangle)$, in the absence or the presence of $20 \mu \mathrm{M}$ atropine. Specific binding of the tracers (defined as an atropine-sensitive fluorescence extinction at $510 \mathrm{~nm}$ ) is expressed in percent of control cell fluorescence. Data fitting to the empirical Hill equation derived for saturation (Supplemental Procedures) allowed the determination of the binding parameters for para-LRB-AC42. Specific LRB-SO ${ }_{3}{ }^{-} \mathrm{Na}^{+}$ binding was fitted according to a linear relationship with tracer concentration (---). B: Competition experiments were performed using $\operatorname{EGFP}(\Delta 17) \mathrm{hM} 1$ cells incubated $\left(4 \mathrm{~h}\right.$ at $\left.20^{\circ} \mathrm{C}\right)$ with $2 \mu \mathrm{M}$ paraLRB-AC42 and increasing concentrations of NMS $(\boldsymbol{\bullet})$, atropine $(\boldsymbol{\nabla})$, AC-42 $(\bullet)$, gallamine $(\boldsymbol{\Lambda})$, N-desmethylclozapine $(\square)$ or Win 51,708 (O). Data from typical experiments, performed in duplicate, are presented as $\mathrm{B} / \mathrm{B}_{0}$ ratios with specific binding $\mathrm{B}_{0}$ taken as the difference in fluorescence levels of samples incubated with the tracer in the absence or the presence of $20 \mu \mathrm{M}$ atropine. Best fits to the most appropriate (competitive or allosteric) model are shown (Supplemental Procedures). Parameters are listed in Table 4.

for their individual sites on the $\operatorname{EGFP}(\Delta 17) \mathrm{hM} 1$ receptor, as determined from radioligand or from FRET equilibrium binding studies, are in remarkable overall agreement.
Taken together, these observations constitute a strong and direct evidence for a bitopic nature of the tracer, with simultaneous occupancy of both the orthosteric and the gallamine allosteric receptor sites.

Molecular Modeling. The three-dimensional structure of the human M1 muscarinic receptor was modeled by homology to the dopamine D3 receptor, which is the most similar GPCR available in the Protein Data Bank to date (about $25 \%$ overall sequence identity and $36 \%$ sequence identity in the seven transmembrane domains (7TMs) with the M1 receptor). Because the position of the conserved cysteine in the second extracellular loop (ECL2) differs in M1 and D3 receptors, this part of the model was reconstructed in order to bury hydrophobic side chains and expose hydrophilic ones while producing nondistorted secondary structure elements. A short molecular dynamic simulation revealed that the extracellular loops are prone to conformational variations whereas the rotameric state of residues in each of the transmembrane helices (TM) is rather well-defined (Figure S2, Supporting Information).

Although our model is not accurate at the atomic resolution, it allows a rough delineation in the M1 receptor of three regions enriched in hydrophobic and negatively charged residues. These regions constitute known and putative anchoring spots for positively charged, orthosteric, and allosteric muscarinic ligands (Figure 8). A selection of key residues in each region is shown in Figure 8A; it includes Trp101 (3.28) and Phe77 (2.56), both reported in the literature for their (concerted) contribution to AC-42 binding and/or function. ${ }^{23,24,26}$ The first region is located within the $7 \mathrm{TMs}$ of the protein (Figure $8 \mathrm{~B}$ ), displays a high content in aromatic residues (Trp101, Tyr106, Tyr381, Tyr404, Tyr408), and exposes the side chains of Asp105 (3.32) and Asn382 (6.52) near its center. It corresponds to the orthosteric site. ${ }^{51,52}$ In the model, its access is obstructed by bulky residues in TM2 (Tyr82, Tyr85) and TM7 (Trp400) and by ECL2. Noteworthy, ECL2 is constrained by the first and third extracellular loops (ECL1 and ECL3, respectively) and covalently linked to TM3, thereby restricting the opening of the orthosteric site whatever the loop conformation (i.e., even if the modeled ECL2 conformations is partly wrong). The second region is located at the receptor surface close to the $\mathrm{N}$-terminal end of the protein chain. It involves the extracellular parts of TM1, TM2, TM3, and TM7 and part of ECL2 (Figure 8C, green). It

Table 4. Parameters for the Interaction of Various Compounds at EGFP $(\Delta 17) \mathrm{hM1}$ Receptors As Defined from Equilibrium Para-LRB-AC42 Binding Studies Performed under FRET Conditions ${ }^{a}$

\begin{tabular}{|c|c|c|c|c|c|c|}
\hline compd & $\mathrm{p} K_{\mathrm{d}}$ & $\mathrm{p} K_{\mathrm{i}}$ & $\mathrm{p} K_{\mathrm{x}}$ & $\log \alpha$ & slope & $\mathrm{p} K_{\left[{ }^{3} \mathrm{H}\right] \mathrm{NMS}}^{b}-\mathrm{p} K_{\text {FRET }}$ \\
\hline para-LRB-AC42 & $6.10 \pm 0.05$ & & & & $1.06 \pm 0.08$ & $-0.10 \pm 0.13$ \\
\hline AC-42 & & $6.05 \pm 0.04$ & & & $1.02 \pm 0.04$ & $-0.29 \pm 0.11$ \\
\hline $\mathrm{AC} 42-\mathrm{NH}_{2}$ & & $5.89 \pm 0.02$ & & & $0.96 \pm 0.04$ & $-0.18 \pm 0.08$ \\
\hline NMS & & $9.77 \pm 0.06$ & & & $1.02 \pm 0.06$ & $0.25 \pm 0.1$ \\
\hline atropine & & $8.92 \pm 0.07$ & & & $1.05 \pm 0.06$ & $0.32 \pm 0.11$ \\
\hline gallamine & & $5.07 \pm 0.04$ & & & $1.04 \pm 0.04$ & $0.23 \pm 0.08$ \\
\hline brucine & & $4.35 \pm 0.06$ & & & $0.91 \pm 0.09$ & $0.24 \pm 0.07$ \\
\hline NDMC & & & $6.92 \pm 0.03$ & $0.74 \pm 0.06$ & $1.02 \pm 0.06$ & $0.30 \pm 0.08$ \\
\hline WIN 51,708 & & & $5.03 \pm 0.05$ & $0.92 \pm 0.02$ & $1.02 \pm 0.05$ & nd \\
\hline
\end{tabular}

${ }^{a}$ Affinity constants ( $-\log M$, mean values \pm SE from three or more independent measurements) are from saturation $\left(K_{\mathrm{d}}\right.$ values $)$ and competition $\left(K_{\mathrm{i}}, K_{x}\right.$, and $\alpha$ values) studies, as detailed in the Experimental Section. Competition experiments were performed at various para-LRB-AC42 concentrations $\left(1 \times\right.$ to $6 \times$ its $K_{\mathrm{d}}$ value) and analyzed according to a competitive $\left(K_{\mathrm{i}}\right)$ or allosteric $\left(K_{x}, \alpha\right)$ model, when appropriate (Supporting Information Procedures). ${ }^{b} \mathrm{p} K^{3} \mathrm{H}[\mathrm{NMS}]$ values are from Table 3. nd: not determined. 

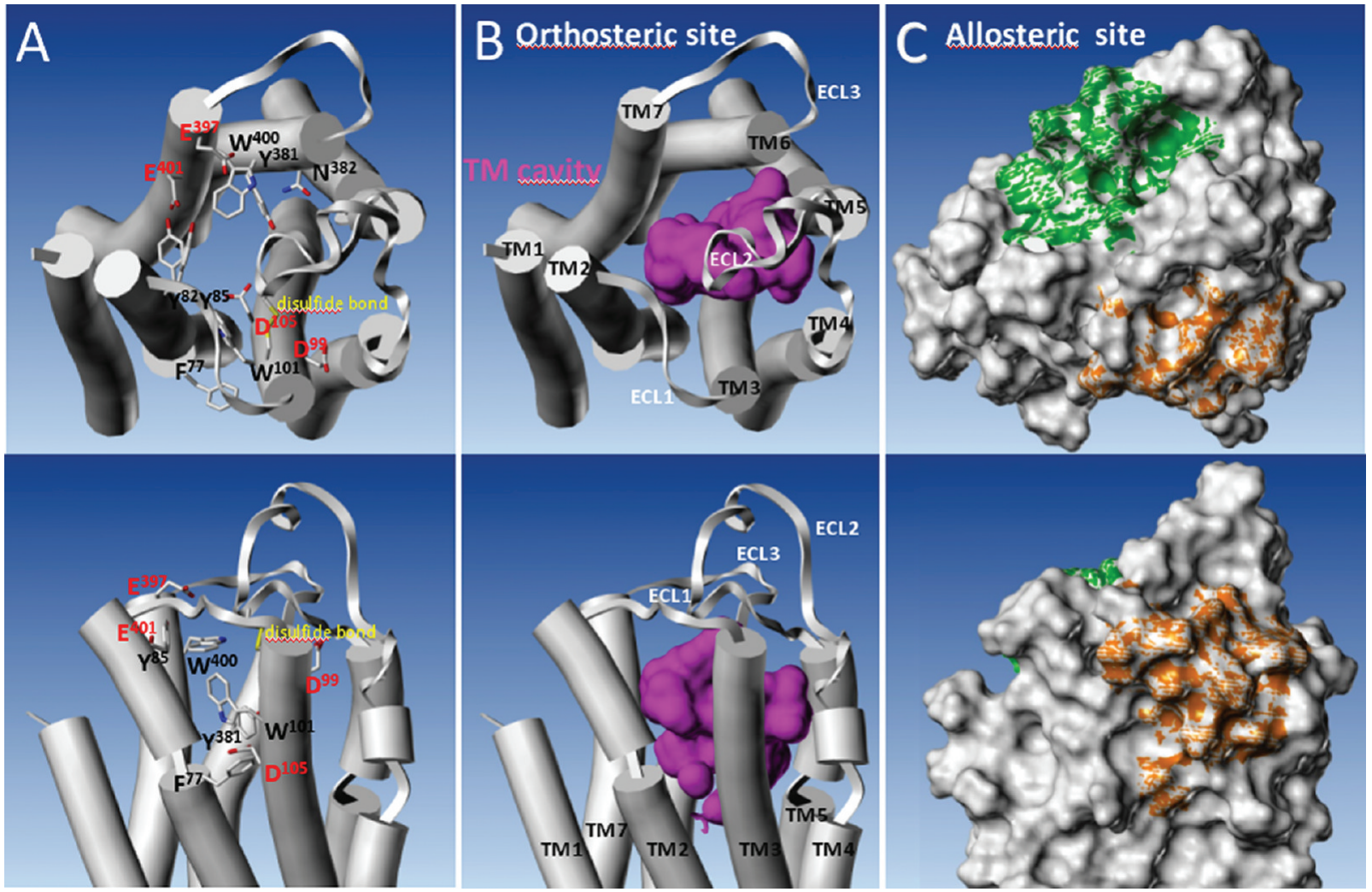

Figure 8. Three-dimensional model of the muscarinic M1 receptor. A: Position of key aromatic residues and solvent accessible charged residues with no vicinal counter charges in the protein chain. The 7TMs are represented by cylinders. The residue side chains are displayed as capped sticks and labeled in red if negatively charged. B: Orthosteric site. The 7TMs are represented by cylinders. The transmembrane cavity is delimitated by its solvent excluded surface colored in magenta. C: Allosteric site. The protein is represented by its solvent excluded surface, which is colored in green and orange around the negatively charged residues and otherwise colored in white. In A, B, and C, top and bottom panels show views from the extracellular side or in the plane of the plasma membrane, respectively. The pictures were made using Sybyl-X (Tripos, Inc., St. Louis, Missouri, USA).

contains Trp400 (7.35) and two negatively charged residues, Glu397 and Glu401 (7.36). The third region is superficial too and resides near the extracellular parts of TM3 and TM4 (Figure 8C; orange). It includes the negatively charged Asp99 (3.26), surrounded by aromatic and hydrophobic residues from ECL1 (Trp91) and ECL2 (Trp164, Tyr166). The three regions are clearly interconnected via common or bridging amino acids. The two superficial domains may be defined as allosteric in nature with respect to the buried orthosteric site. Moreover, they contain several residues (Asp99, Trp101, Trp400, for example) involved in gallamine binding. ${ }^{42}$ They surround the route leading to the central binding site and may thus also participate in the primary docking step of orthosteric ligands. ${ }^{53}$

This M1 model provides the structural foundations for further discussion of our experimental data on AC-42 and its fluorescent derivatives.

\section{DISCUSSION AND CONCLUSION}

There is no doubt that novel M1 agonists, such as AC-42 and its analogues, together with TBPB and NDMC, display a mixed orthosteric/allosteric binding behavior. On one hand, they exhibit competitive-like properties when tested against classical orthosteric compounds in both equilibrium binding and functional assays. $^{12,13,23,24}$ On the other hand, their ability to retard $\left[{ }^{3} \mathrm{H}\right] \mathrm{NMS}$ dissociation and their particular pattern of response to mutations of key orthosteric residues are taken as evidence for allosteric properties. ${ }^{10-12,14,23,26}$ An emerging idea, supported by the current view (and our M1 model) that muscarinic orthosteric and allosteric sites are in proximity and even on the access way to each other, ${ }^{48,54}$ is to consider these compounds as bitopic, i.e., able to recognize epitopes within both orthosteric and allosteric sites and to interact with them simultaneously. ${ }^{24}$ How robust is the interpretation of point mutagenesis studies regarding the definition of topographically distinct or overlapping binding domains? Do novel agonists exhibit different binding poses on free or $\left[{ }^{3} \mathrm{H}\right] \mathrm{NMS}$-occupied receptors? What are the structural determinants of these molecules responsible for such hybrid properties ?

Within this very challenging context, traceable novel agonists may be regarded as tools of choice to get direct information on their interaction with the M1 receptor. Tritiated AC-42 could have been an ideal candidate, as it retains the structure and the activity of the original molecule. However, given its micromolar affinity, high nonspecific binding levels, fast dissociation kinetics, and other difficulties are expected, as was encountered with the $\left[{ }^{3} \mathrm{H}\right]$ dimethyl-W84 radioalloster. ${ }^{55}$ We thus considered the possibility of fluorescent derivatives of AC-42 to behave as tracers enabling direct monitoring of binding events through fluorescence resonance energy transfer (FRET) from EGFP-fused M1 receptors. This technology is now welladmitted as a powerful alternative to radioligand binding assays, prone to fine, temporal, and quantitative description of complex binding mechanisms. ${ }^{7,27,28,56}$ The $\operatorname{EGFP}(\Delta 17) \mathrm{hM1}$ construct, with EGFP fused to a truncated receptor N-terminus, ${ }^{27}$ was 

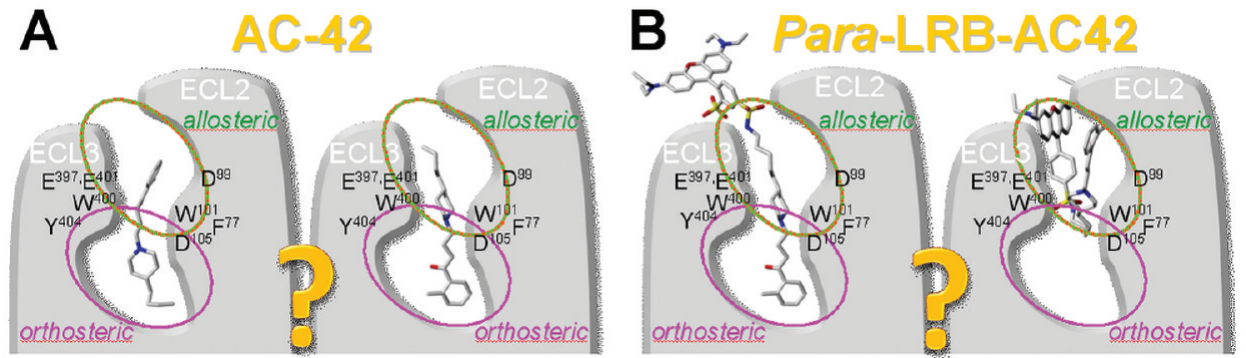

Figure 9. Hypothetical binding modes of AC-42 and para-LRB-AC42 to the M1 muscarinic receptor. A: Upside-down positions of AC-42 within the 7TMs cavity. The orthosteric site is circled in magenta; the allosteric site is dashed in green-orange to reconcile the two regions depicted in Figure 8C. B: Two possible bitopic binding modes for para-LRB-AC42. For a sake of clarity, ligands are presented as CPK colored sticks and hydrogen atoms are omitted. In the representation, the scale of the receptor is slightly smaller than that of the ligand. In our three-dimensional model, the distances between negatively charged residues range from $13 \AA$ to $17 \AA$.

validated here as a suitable tool for examining AC-42 properties. Indeed, and in contrast with previous observations, ${ }^{10}$ neither the fusion of EGFP nor the deletion of the receptor $\mathrm{N}$-terminus significantly affects $\mathrm{AC}-42$ agonism and affinity properties. Moreover, the $\operatorname{EGFP}(\Delta 17) \mathrm{hM} 1$ chimera shares with the wild type hM1 receptor superimposable affinity and modulatory properties for a series of prototypical orthosteric and allosteric molecules.

Four fluorescent compounds, i.e., the LRB moiety alone (LRB-SO ${ }_{3}^{-} \mathrm{Na}^{+}$) or substituted in the para position with a butyl chain (para-LRB-n-butyl 20) and its two isomers linked to AC42- $\mathrm{NH}_{2}$ (ortho-LRB-AC42 $\mathbf{2 a}$ and para-LRB-AC42 2b), were synthesized and characterized. Solubility measurements, supported by biological evidence (partial inhibition in functional and binding experiments), pointed to serious limitations in the use of para-LRB- $n$-butyl and ortho-LRB-AC42. Affinity parameters for para-LRB- $n$-butyl could not be determined with great precision, but the presence of a butyl chain in the para position (and the concomitant neutralization of $\mathrm{S} \mathrm{SO}_{3}{ }^{-}$charge) clearly confers to this molecule the ability to bind to M1 receptors in the micromolar concentration range, as opposed to the millimolar affinity of $\mathrm{LRB}-\mathrm{SO}_{3}{ }^{-} \mathrm{Na}^{+}$.

AC-42, AC42- $\mathrm{NH}_{2}$, and para-LRB-AC42 display fairly similar affinity constants for the receptor, although the modifications we introduced within AC-42 converted the compounds into antagonists. One explanation is that the exchange of the AC-42 butyl chain for a pentyl one and the concomitant addition of a second protonated amino group in AC42- $\mathrm{NH}_{2}$ may disrupt an essential ionic bond (presumably between the positively charged AC-42 piperidine nitrogen and the receptor Asp105 carboxylate) and/or alter a preferential orientation of the AC42 aliphatic chain within the receptor, two critical aspects for AC-42 agonism. ${ }^{23,24}$ Such explanations probably do not apply to para-LRB-AC42, as its hardly basic sulfonamido group remains neutral at physiological $\mathrm{pH}$.

Numerous control FRET experiments were performed under equilibrium and kinetic conditions, taking para-LRB-AC42 as the tracer and using pure EGFP, nontransfected HEK cells, and cells overexpressing the $\operatorname{EGFP}(\Delta 17) \mathrm{hM} 1$ or other EGFP-fused receptors. They allowed ligand emission interference and an unexpected artifact of AC-42 (and AC42- $\mathrm{NH}_{2}$ ) on cell autofluorescence to be detected, quantified, and carefully corrected. They provided operational criteria for a robust definition of the specificity of FRET signals. FRET and $\left[{ }^{3} \mathrm{H}\right] \mathrm{NMS}$ binding experiments provided nicely concordant affinity parameters for all orthosteric and allosteric compounds included in this study. Altogether, we demonstrate that specific
para-LRB-AC42 binding takes place on M1 muscarinic receptors.

What do we learn about the interaction of para-LRB-AC42 (and AC-42) with $\operatorname{EGFP}(\Delta 17) \mathrm{hM} 1$ receptors ? From the orthosteric point of view ([$\left.{ }^{3} \mathrm{H}\right] \mathrm{NMS}$ binding studies), paraLRB-AC42 may be regarded as an unlabeled compound that shares several properties with AC-42: it binds to $\left[{ }^{3} \mathrm{H}\right] \mathrm{NMS}$ sites in a competitive manner, exhibits an affinity comparable to that of AC-42, and slows $\left[{ }^{3} \mathrm{H}\right] \mathrm{NMS}$ dissociation in a concentrationdependent manner. As the presence of the fluorophore in the para position is almost neutral in terms of affinity, and preserves the allosteric character of the molecule at $\left[{ }^{3} \mathrm{H}\right] \mathrm{NMS}$ occupied receptors as well as $\mathrm{M} 1 / \mathrm{M} 3$ selectivity, it is tempting to suggest that the contribution of LRB to overall para-LRB-AC42 binding energy is negligible and that it does not significantly alter proper positioning of the AC-42 moiety on the M1 receptor.

Under FRET conditions, para-LRB-AC42 exhibits the potential of a micromolar affinity tracer. Moreover, it provides the first direct evidence for a bitopic binding mode on free M1 receptors: its interaction with the $\operatorname{EGFP}(\Delta 17) \mathrm{hM} 1$ receptor is inhibited by both orthosteric and allosteric ligands, as well as by AC-42, in a competitive manner. Specific para-LRB-AC42 binding to M1 receptors is abolished (together with AC-42 function and specific $\left[{ }^{3} \mathrm{H}\right] \mathrm{NMS}$ binding) following covalent binding of PrBCM to the orthosteric Asp105 (3.32) receptor residue. Whether this bulky affinity label precludes a direct interaction of the fluorescent probe with Asp105 or sterically hinders its access to surrounding residues remains to be clarified. Importantly, the allosteric binding component of paraLRB-AC42 clearly targets the gallamine site, as Win 51,708 and NDMC display a typical noncompetitive binding behavior. Such a view provides additional support to the indirect information by Avlani et al. ${ }^{24}$ on the competitive nature of 77-LH-28-1 and $\mathrm{C}_{7} / 3$-phth (an allosteric modulator that binds to the gallamine site $\left.{ }^{57}\right)$ at the $\left[{ }^{3} \mathrm{H}\right] \mathrm{NMS}$ occupied $\mathrm{M} 1$ receptor. Refined kinetic investigations, such as real-time FRET monitoring of para-LRB-AC42 binding properties, were hampered by very fast association and dissociation $\left(k_{\text {off }}=\right.$ $0.65 \pm 0.01 \mathrm{~s}^{-1}$ at $\left.20{ }^{\circ} \mathrm{C} ; n=5\right)$ rates. For comparison, the offrate of para-LRB-AC42 was about 10 times faster than that estimated for the nanomolar radioalloster $\left[{ }^{3} \mathrm{H}\right]$ dimethyl-W84 $\left(0.07 \mathrm{~s}^{-1}\right)$ on the $\mathrm{M} 2$ receptor. ${ }^{55}$

What are the orthosteric and allosteric molecular determinants in the para-LRB-AC42 and AC-42 molecules? FRET measurements of donor/acceptor distances indicate that this tracer, when bound to the $\operatorname{EGFP}(\Delta 17) \mathrm{hM} 1$ receptor, locates its LRB fluorophore at a greater distance from EGFP (59 $\AA$ ) 
than do a series of fluorescent Bodipy or Rhodamine Red-X pirenzepine derivatives. ${ }^{38}$ Some of them, including $\mathrm{RR}(17) \mathrm{PZ}$, were already pointed out for their bitopic binding properties: the pirenzepine moiety binds to the orthosteric site, whereas the Bodipy (or Rhodamine Red) fluorophore is stacked within the classical M1 allosteric binding site (at 45-50 $\AA$ from EGFP) and competes with brucine (and gallamine) for binding to the receptor. ${ }^{38}$ Clearly, the possibility for the fluorophore in para-LRB-AC42 to occupy the classical gallamine site is unlikely. The para-LRB- $n$-butyl and ortho-LRB-AC42 derivatives would have been valuable tools to further dissect the molecular bases for the bitopic binding pose of the fluorescent derivative. Unfortunately, these expectations fell short because of solubility limitations incompatible with the micromolar affinity of these two compounds. Thus, to gain insight into M1 receptor domains that may accommodate para-LRB-AC42 (and AC-42), the three-dimensional structure of the receptor was modeled by homology to the dopamine D3 receptor. As the M1 model was built from a distant homologue, we felt it was not reliable enough to conduct an automated docking approach. Preliminary trials, using different docking tools and alternative receptor conformations generated by molecular dynamics, indeed did not predict a consensual meaningful pose for AC-42 and its derivatives (data not shown). This is the reason why the coming discussion will not focus on possible intermolecular interactions but instead will suggest which binding modes best agree with the geometric and electrostatic properties of the ligands and the M1 receptor.

According to our three-dimensional model, the orthosteric site in the 7TMs (with its typical cleft shape) is wide and deep enough to bury AC-42 and bulkier ligands (Figure 9A). The volume of the protein cavity is about $540 \AA^{3}$ (and could be even larger if ECL2 would not close the site entrance), whereas the volume of AC-42, in an extended conformation, is only about $340 \AA^{3}$. The degree of penetration and the relative position of AC- 42 within the receptor cavity are hardly predictable because it is a flexible and pseudosymmetrical molecule. The selection of the AC-42 active conformer among a profusion of possibilities requires an accurate definition of the receptor three-dimensional structure. In addition, the central position of the positively charged piperidine of $\mathrm{AC}-42$ precludes the hypothesis of a preferential orientation of this ligand in the vicinity of the receptor extracellular domains that display an overall negative electrostatic potential. Accordingly, the literature reports on different docking orientations and positions of AC-42 into the M1 muscarinic receptor. ${ }^{23,24,26}$ Nevertheless, all the binding poses proposed for AC-42 (two examples are shown in Figure 9A, right and left) practically agree with experimental observations based on site-directed mutagenesis of the M1 receptor. In particular, several aromatic residues such as Trp101, Phe77, and the less consensual Tyr404 were shown to be important determinants for AC-42 binding and function, probably by controlling the accessibililty of the transmembrane cavity. ${ }^{23,24,26}$ According to our model, these residues, possibly together with Trp400, constitute a gateway between the orthosteric and the allosteric sites. If one considers the additional possibility of AC-42 to interact with the orthosteric Asp105 residue, ${ }^{12,23}$ it becomes obvious that the molecule may overlap both the orthosteric and allosteric sites and thus exhibit a bitopic binding pose. Several points, however, need to be clarified. Indeed, given the presence of important steric constraints in the unoccupied M1 receptor, one may suspect that extended and embedded binding poses for AC-42 may not predominate. Moreover, such positions hardly reconcile with the observation of allosteric binding properties for AC-42 on $\left[{ }^{3} \mathrm{H}\right] \mathrm{NMS}$-occupied receptors (this study and references therein). ${ }^{11,12}$

The introduction of the LRB fluorophore onto AC42- $\mathrm{NH}_{2}$ results in an elongation of about $10 \AA$ of the molecule, thereby restraining the number of accessible positions for $\mathrm{AC}-42$ within the cavity (Figure 9B). Both AC-42 and the AC-42 moiety of para-LRB-AC42 may occupy the same region in the receptor (Figure 9A right and Figure 9B left) so that the bulky fluorophore is placed next to ECL2 and ECL3 on top of (or in partial overlap with) the allosteric site. An alternative binding mode would correspond to the switch of the AC-42 moiety of para-LRB-AC42 toward the extracellular allosteric domains of the receptor (Figure 9B right). The piperidine ring could hence establish an ionic bond in the gallamine allosteric domain, while LRB would occupy the opposite side of the allosteric site (orange or green patches in Figure 8C), leaving a place for the linker between AC-42 and the fluorophore to explore the top of the orthosteric site. Although such a more superficial pose agrees better with very fast para-LRB-AC42 binding kinetics, both assumptions explain well why the distance between the LRB and EGFP fluorophores is $10 \AA$ longer than that estimated by FRET, on the same receptor, using pirenzepine derivatives known to stack their Bodipy or Rhodamine Red fluorophore within the gallamine site.

Future mutagenesis mapping studies should provide further information on the $\mathrm{M} 1$ receptor domains that accommodate AC-42 and the para-LRB-AC42 derivative. Although the interpretation of such data is often ambiguous regarding the definition of topographically distinct or overlapping binding sites, one may expect interesting clues from the effects of the mutation of the negatively charged amino acids (Asp 99, Glu397, Glu 401) and of the aromatic Trp101 and Trp 400 residues. Indeed, they may orientate the choice among the possibilities depicted in Figure 9, help define the allosteric subdomains occupied by these ligands, give additional support to or invalidate the possibility of a similar binding pose for $\mathrm{AC}$ 42 and the AC-42 moiety of para-LRB-AC42, and perhaps allow the extension of FRET experiments using the ortho-LRBAC42 and para-LRB- $n$-butyl tools.

In conclusion, this study provides new pieces of evidence for a bitopic nature of AC-42 binding on M1 receptors. Our strategy may be compared with the "fragment approach" that revealed the bitopic nature of McN-A-343 at M2 receptors, ${ }^{58}$ with the additional possibility here of monitoring the binding properties of intermediates and final compounds through FRET. Interpretation of such data is not straightforward, as isolated or fused fragments do not necessarily occupy the same binding pockets. Linker orientation, length, and nature are critical factors for sculpting affinity, potency, and site-targeting of hybrid molecules. ${ }^{38,59}$ It remains that dualsteric, hybrid, or bitopic molecules may combine high affinity (orthosteric fragment) and subtype-selective (allosteric fragment) receptor binding to engender functional selectivity. ${ }^{60,61}$ Their rational design and development are expected to provide further insights into ligand binding mechanisms and to improve the specificity of therapeutic GPCR activation.

\section{EXPERIMENTAL SECTION}

General Chemistry. [N-Methyl $\left.{ }^{3} \mathrm{H}\right]$ scopolamine chloride $\left(\left[{ }^{3} \mathrm{H}\right] \mathrm{NMS}, 82 \mathrm{Ci} / \mathrm{mmol}\right)$ and quinuclidinyl [phenyl-4- $\left.{ }^{3} \mathrm{H}\right]$ benzilate $\left(\left[{ }^{3} \mathrm{H}\right] \mathrm{QNB}, 30 \mathrm{Ci} / \mathrm{mmol}\right)$ were from Perkin Elmer Life and Analytical 
Sciences (Courtaboeuf, France). Atropine sulfate, NMS bromide, pirenzepine dihydrochloride, carbachol chloride, $\mathrm{N}$-desmethylclozapine hydrochloride, gallamine triethiodide, and WIN 51,708 hydrate were purchased from Sigma-Aldrich (Saint-Quentin Fallavier, France). Indo-1-acetoxymethyl ester was supplied by Molecular Probes (Invitrogen, Cergy Pontoise, France). Lissamine rhodamine B sodium sulfonate (LRB-SO ${ }_{3}{ }^{-} \mathrm{Na}^{+}$, sulforhodamine B) was from TCI Europe (Zwijndrecht, Belgium) and lissamine rhodamine B sulfonyl chloride (mixed isomers) from Acros Organics (Halluin, France). 4- $n$-Butyl-1[4-(2-methylphenyl)-4-oxo-1-butyl]piperidine hydrogen chloride (AC42) was a generous gift from Dr. T. Spalding (Acadia Pharmaceuticals Inc., San Diego, CA) and Pr. A. Christopoulos (Monash University, Victoria, Australia). Propylbenzilylcholine mustard was generously provided by Dr. N. Birdsall (NIMR, London, U.K.).

${ }^{1} \mathrm{H}$ NMR spectra were recorded on a Bruker Advance spectrometer. Chemical shifts ( $\delta$ values) are expressed in ppm relative to internal solvent peaks, and coupling constants $(J)$ are measured in hertz. Signals are described as $\mathrm{s}$ (singlet), $\mathrm{d}$ (doublet), $\mathrm{t}$ (triplet), $\mathrm{m}$ (multiplet), and brs (broad singlet). Analytical reverse-phase high performance liquid chromatography (RP-HPLC) separations were performed on a C18 Symmetry Shield column $(4.6 \mathrm{~mm} \times 150 \mathrm{~mm})$ using a linear gradient (100\% A for $1 \mathrm{~min}$ and then $0 \%$ to $100 \% \mathrm{~B}$ in $30 \mathrm{~min}$, flow rate of $\left.1 \mathrm{~mL} \cdot \mathrm{min}^{-1}\right)$ of solvent $\mathrm{B}\left(100 \% \mathrm{CH}_{3} \mathrm{CN}, 0.1 \%\right.$ TFA, v/v) in solvent $\mathrm{A}\left(100 \% \mathrm{H}_{2} \mathrm{O}, 0.1 \%\right.$ TFA, v/v). Detection was set at 220 and $254 \mathrm{~nm}$. Purified final compounds eluted as single and symmetrical peaks (thereby confirming a purity of $\geq 95 \%$ ) at retention times $\left(t_{\mathrm{R}}\right)$ given below. Their identity was determined by highresolution mass spectra (HRMS) which were acquired on a Bruker MicroTof mass spectrometer, using electrospray ionization (ESI) and a time-of-flight analyzer (TOF).

UV-visible absorbance spectroscopy was done with a Cary $1 \mathrm{E}$ spectrophotometer (Varian). Fluorescence measurements were made using a SPEX Fluorolog 2 (Jobin Yvon Horiba) spectrofluorimeter.

4-[4-(5-Aminopentyl)piperidinyl]-1-o-tolylbutanone, $\mathrm{HCl}$ Salt (1). To a solution of methyl sulfonate $7(285 \mathrm{mg}, 0.95 \mathrm{mmol})$ and piperidine derivative $8(255 \mathrm{mg}, 0.95 \mathrm{mmol})$ in acetonitrile (10 $\mathrm{mL}$ ) was added triethylamine $(198 \mu \mathrm{L}, 1.42 \mathrm{mmol})$. The mixture was heated at $110^{\circ} \mathrm{C}$ overnight in a sealed tube and concentrated in vacuo to a residue. Subsequent purification by flash chromatography (EtOAc/MeOH, 5/95, v/v) gave access to the tert-butyl 5-[1-(3-(2$o$-tolyl-1,3-dioxolan-2-yl)propyl)piperidin-4-yl]pentylcarbamate compound 9 (90 mg, 20\%) which was dissolved in a $1 \mathrm{~N} \mathrm{HCl} / \mathrm{Et}_{2} \mathrm{O}$ solution and stirred for $1 \mathrm{~h}$ at room temperature. The solvent was removed under reduced pressure and the residue triturated in ether to give 1 as a salt $(52 \mathrm{mg}, 84 \%)$. RP-HPLC purity $>95 \%$; $t_{\mathrm{R}}=16.8 \mathrm{~min}$. ${ }^{1} \mathrm{H}$ NMR $\left(300 \mathrm{MHz}, \mathrm{CD}_{3} \mathrm{OD}\right): \delta 7.77(\mathrm{~d}, J=8.2 \mathrm{~Hz}, 1 \mathrm{H}), 7.39-7.24$ $(\mathrm{m}, 3 \mathrm{H}), 3.30-3.27(\mathrm{~m}, 2 \mathrm{H}), 3.19-3.13(\mathrm{~m}, 4 \mathrm{H}), 3.09-2.88(\mathrm{~m}, 4 \mathrm{H})$, $2.45(\mathrm{~s}, 3 \mathrm{H}), 2.40-2.37(\mathrm{~m}, 2 \mathrm{H}), 2.12-2.10(\mathrm{~m}, 2 \mathrm{H}), 1.60-1.34(\mathrm{~m}$, $6 \mathrm{H}), 1.29-1.14$ (m, 5H). HRMS: calcd for $\mathrm{C}_{21} \mathrm{H}_{35} \mathrm{~N}_{2} \mathrm{O}$ 331.2744, found 331.2742

Para-LRB-AC42 (2a) and Ortho-LRB-AC42 (2b), Trifluoroacetate Salt. To a solution of lissamine rhodamine B sulfonyl chloride $(72 \mathrm{mg}, 125 \mu \mathrm{mol})$ in $\mathrm{CHCl}_{3}(0.3 \mathrm{M})$ at $0{ }^{\circ} \mathrm{C}$ were added 4-[4-(5aminopentyl)piperidinyl]-1-o-tolylbutanone $1(50 \mathrm{mg}, 125 \mu \mathrm{mol})$ and triethylamine ( $60 \mu \mathrm{L}, 437 \mu \mathrm{mol})$. The mixture was stirred overnight at room temperature, then concentrated under reduced pressure. Isolation of both ortho and para isomers of lissamine rhodamine $\mathrm{B}$ labeled AC-42 was performed by preparative RP-HPLC on a C18 Symmetry Shield column $(19 \mathrm{~mm} \times 300 \mathrm{~mm})$ equilibrated in solvent A $\left(100 \% \mathrm{H}_{2} \mathrm{O}, 0.1 \%\right.$ TFA, v/v). Elution proceeded with a linear gradient from $20 \%$ to $70 \%$ of solvent $\mathrm{B}\left(100 \% \mathrm{CH}_{3} \mathrm{CN}, 0.1 \%\right.$ TFA, v/ v) in solvent $A$ in $40 \mathrm{~min}$ at a $10 \mathrm{~mL} \cdot \mathrm{min}^{-1}$ flow rate. Detection was set at 220 and $254 \mathrm{~nm}$. Fractions containing the products of interest were pooled, concentrated, and further checked for purity by analytical RP-HPLC and HRMS as indicated.

Para-LRB-AC42 (2a, purple powder, $35 \mathrm{mg}, 30 \%):{ }^{1} \mathrm{H}$ NMR $\left(\right.$ DMSO $\left._{6}, 500 \mathrm{MHz}\right) \delta 8.44(\mathrm{~d}, J=1.9 \mathrm{~Hz}, 1 \mathrm{H}), 7.92(\mathrm{dd}, J=7.9$ and $1.9 \mathrm{~Hz}, 1 \mathrm{H}), 7.81(\mathrm{t}, J=5.8 \mathrm{~Hz}, 1 \mathrm{H}), 7.75(\mathrm{dd}, J=7.7$ and $1.4 \mathrm{~Hz}$, $1 \mathrm{H}), 7.47(\mathrm{~d}, J=7.9 \mathrm{~Hz}, 1 \mathrm{H}), 7.44(\mathrm{td}, J=7.5$ and $1.3 \mathrm{~Hz}, 1 \mathrm{H}), 7.34-$ $7.29(\mathrm{~m}, 2 \mathrm{H}), 7.05-6.98(\mathrm{~m}, 4 \mathrm{H}), 6.93(\mathrm{~d}, J=2.3 \mathrm{~Hz}, 2 \mathrm{H}), 3.70-3.60$ (m, 8H), 3.48 (bd, $J=12.2 \mathrm{~Hz}, 2 \mathrm{H}), 3.08-3.02(\mathrm{~m}, 4 \mathrm{H}), 2.94-2.87$ (m, 4H), $2.41(\mathrm{~s}, 3 \mathrm{H}), 2.00-1.85(\mathrm{~m}, 4 \mathrm{H}), 1.51-1.45(\mathrm{~m}, 3 \mathrm{H}), 1.37-$ $1.21(\mathrm{~m}, 20 \mathrm{H}) .{ }^{13} \mathrm{C}$ NMR (DMSO- $\left.d_{6}, 100 \mathrm{MHz}\right): \delta 157.8,157.5$, $157.3,157.0,155.0,147.9,141.5,137.3,137.0,132.9,132.6,131.6$, 130.6, 128.6, 128.4, 126.5, 125.9, 125.6, 113.6, 113.4, 95.4, 55.5, 52.0, 45.2, 42.4, 37.5, 35.0, 32.5, 29.1, 28.9, 25.9, 25.2, 20.8, 18.2, 12.4 (bs). RP-HPLC purity: $95 \%$; $t_{\mathrm{R}}=18.9 \mathrm{~min}$. HRMS: calcd for $\mathrm{C}_{48} \mathrm{H}_{63} \mathrm{~N}_{4} \mathrm{O}_{7} \mathrm{~S}_{2}$ 871.4133, found 871.4122

Ortho-LRB-AC42 (2b, purple powder, $10 \mathrm{mg}, 10 \%):{ }^{1} \mathrm{H}$ NMR $\left(\right.$ DMSO$\left.d_{6}, 500 \mathrm{MHz}\right) \delta 8.40(\mathrm{~d}, J=1.5 \mathrm{~Hz}, 1 \mathrm{H}), 8.02(\mathrm{dd}, J=7.8$ and $1.5 \mathrm{~Hz}, 1 \mathrm{H}), 7.94(\mathrm{t}, J=5.6 \mathrm{~Hz}, 1 \mathrm{H}), 7.79(\mathrm{dd}, J=7.4$ and $1.2 \mathrm{~Hz}$, $1 \mathrm{H}), 7.47-7.43(\mathrm{~m}, 2 \mathrm{H}), 7.35-7.30(\mathrm{~m}, 2 \mathrm{H}), 7.08(\mathrm{dd}, J=9.6$ and 2.4 $\mathrm{Hz}, 2 \mathrm{H}), 6.99$ (d, $J=9.5 \mathrm{~Hz}, 2 \mathrm{H}), 6.96(\mathrm{~d}, J=2.4 \mathrm{~Hz}, 2 \mathrm{H}), 3.65(\mathrm{q}, J$ $=7.2 \mathrm{~Hz}, 8 \mathrm{H}), 3.49-3.47(\mathrm{~m}, 2 \mathrm{H}), 3.08-3.05(\mathrm{~m}, 4 \mathrm{H}), 2.92-2.83(\mathrm{~m}$, $3 \mathrm{H}), 2.73(\mathrm{t}, J=6.9 \mathrm{~Hz}, 1 \mathrm{H}), 2.41(\mathrm{~s}, 3 \mathrm{H}), 2.00-1.92(\mathrm{~m}, 2 \mathrm{H}), 1.83-$ $1.80(\mathrm{~m}, 2 \mathrm{H}), 1.33-1.15(\mathrm{~m}, 23 \mathrm{H}) .{ }^{13} \mathrm{C}$ NMR (DMSO- $\left.d_{6}, 100 \mathrm{MHz}\right)$ : $\delta 157.6,157.1,155.2,155.1,152.2,150.4,148.4,139.9,139.6,137.3$, $137.0,131.6,131.4,131.0,130.3,129.5,129.2,128.6,125.9,125.6$, 114.2 , 113.5, 95.7, 55.5, 52.0, 45.3, 42.2, 37.6, 35.0, 32.5, 29.1, 28.8, 25.9, 25.1, 20.8, 18.2, 12.4 (bs). RP-HPLC purity: $>95 \%$; $t_{\mathrm{R}}=18.0$ min. HRMS: calcd for $\mathrm{C}_{48} \mathrm{H}_{63} \mathrm{~N}_{4} \mathrm{O}_{7} \mathrm{~S}_{2} 871.4133$, found 871.4138.

4-(2-Methylphenyl)-4-oxobutanoic Acid (3). o-Tolylmagnesium bromide $(2.0 \mathrm{M}$ in diethyl ether, $5.5 \mathrm{~mL}$ ) was added to a solution of succinic anhydride $(1 \mathrm{~g}, 10 \mathrm{mmol})$ in anhydrous THF $(20 \mathrm{~mL})$ at $-78{ }^{\circ} \mathrm{C}$. The mixture was stirred at room temperature for $2 \mathrm{~h}$, then diluted in $\mathrm{CH}_{2} \mathrm{Cl}_{2}$, washed with a $1 \mathrm{M} \mathrm{HCl}$ solution, $10 \% \mathrm{NaHCO}_{3}$, and brine solutions, and finally dried over $\mathrm{MgSO}_{4}$. The solvent was removed under reduced pressure and the crude product was purified by flash chromatography using an EtOAc/hexane $(2 / 8, \mathrm{v} / \mathrm{v})$ solution as eluant. $R_{f}=0.15$, white solid $(1.88 \mathrm{~g}, 98 \%) .{ }^{1} \mathrm{H}$ NMR $(300 \mathrm{MHz}$, $\left.\mathrm{CDCl}_{3}\right): \delta 7.69(\mathrm{~d}, J=8.2 \mathrm{~Hz}, 1 \mathrm{H}), 7.42-7.25(\mathrm{~m}, 3 \mathrm{H}), 3.24(\mathrm{t}, J=$ $6.2 \mathrm{~Hz}, 2 \mathrm{H}), 2.80(\mathrm{t}, J=6.2 \mathrm{~Hz}, 2 \mathrm{H}), 2.51(\mathrm{~s}, 3 \mathrm{H})$.

Methyl 4-(2-Methylphenyl)-4-oxobutanoate (4). A solution of acid $3(500 \mathrm{mg}, 2.6 \mathrm{mmol})$ in $30 \mathrm{~mL}$ of methanol with sulfuric acid $(50 \mu \mathrm{L})$ was refluxed overnight. The solvent was removed under reduced pressure, then diluted with EtOAc and washed with $10 \%$ $\mathrm{NaHCO}_{3}$, brine and dried over $\mathrm{MgSO}_{4}$. After solvent removal under reduced pressure, the product was isolated by flash chromatography using an EtOAc/hexane $(2 / 8, \mathrm{v} / \mathrm{v})$ solution as eluant. $R_{f}=0.45$, white solid (380 mg, 71\%). ${ }^{1} \mathrm{H}$ NMR (200 MHz, $\left.\mathrm{CDCl}_{3}\right): \delta 7.74(\mathrm{~d}, J=8.2$ $\mathrm{Hz}, 1 \mathrm{H}), 7.46-7.30(\mathrm{~m}, 3 \mathrm{H}), 3.74(\mathrm{~s}, 3 \mathrm{H}), 3.26(\mathrm{t}, J=6.3 \mathrm{~Hz}, 2 \mathrm{H})$, $2.78(\mathrm{t}, J=6.3 \mathrm{~Hz}, 2 \mathrm{H}), 2.53(\mathrm{~s}, 3 \mathrm{H})$.

Methyl 3-[2-(2-Methylphenyl)-1,3-dioxolan-2-yl]propanoate (5). To a solution of ester $4(380 \mathrm{mg}, 1.84 \mathrm{mmol})$ in benzene (30 $\mathrm{mL}$ ), in the presence of a catalytic amount of $p$-toluenesulfonic acid, was added ethylene glycol $(114 \mathrm{mg}, 1.84 \mathrm{mmol})$. The resulting mixture was refluxed for 2 days. Then the solvent was removed under reduced pressure and the crude product was diluted in EtOAc, washed with a brine solution, and dried over $\mathrm{MgSO}_{4}$. The product was used without any further purification (460 mg, quantitative yield). ${ }^{1} \mathrm{H}$ NMR (300 $\left.\mathrm{MHz}, \mathrm{CDCl}_{3}\right): \delta 7.50(\mathrm{~d}, J=8.2 \mathrm{~Hz}, 1 \mathrm{H}), 7.39-7.13(\mathrm{~m}, 3 \mathrm{H}), 4.00-$ $3.98(\mathrm{~m}, 2 \mathrm{H}), 3.80-3.77(\mathrm{~m}, 2 \mathrm{H}), 3.64(\mathrm{~s}, 3 \mathrm{H}), 3.23(\mathrm{t}, J=6.3 \mathrm{~Hz}$, $2 \mathrm{H}), 2.75(\mathrm{t}, J=6.3 \mathrm{~Hz}, 2 \mathrm{H}), 2.51(\mathrm{~s}, 3 \mathrm{H})$.

3-[2-(2-Methylphenyl)-1,3-dioxolan-2-yl]propanol (6). To a solution of ester $5(500 \mathrm{mg}, 2 \mathrm{mmol})$ in ether $(10 \mathrm{~mL})$, stirred at $0{ }^{\circ} \mathrm{C}$, was added $\mathrm{LiAlH}_{4}(100 \mathrm{mg}, 2.6 \mathrm{mmol})$. After $1 \mathrm{~h}$ of agitation at room temperature, the solvent was removed under reduced pressure. The crude oily product was diluted in EtOAc, washed with water, a brine solution, and then dried over $\mathrm{MgSO}_{4}$. Following removal of the solvent under reduced pressure, the crude product was purified on flash chromatography using an EtOAc/hexane mixture $(5 / 5, \mathrm{v} / \mathrm{v})$ to give 6 as a yellow oil $(205 \mathrm{mg}, 48 \%) .{ }^{1} \mathrm{H}$ NMR $\left(300 \mathrm{MHz}, \mathrm{CDCl}_{3}\right): \delta$ $7.50(\mathrm{~d}, J=8.2 \mathrm{~Hz}, 1 \mathrm{H}), 7.20-7.14(\mathrm{~m}, 3 \mathrm{H}), 4.06-4.03(\mathrm{~m}, 2 \mathrm{H})$, $4.02-3.75(\mathrm{~m}, 2 \mathrm{H}), 3.64(\mathrm{t}, J=6.2 \mathrm{~Hz}, 2 \mathrm{H}), 2.51(\mathrm{~s}, 3 \mathrm{H}), 2.06(\mathrm{t}, J=$ $6.4 \mathrm{~Hz}, 2 \mathrm{H}), 1.95(\mathrm{bs}, 1 \mathrm{H}), 1.73-1.69(\mathrm{~m}, 2 \mathrm{H})$.

3-[2-(2-Methylphenyl)-1,3-dioxolan-2-propyl Methylsulfonate (7). To a solution of alcohol $6(210 \mathrm{mg}, 0.95 \mathrm{mmol})$ in $\mathrm{CH}_{2} \mathrm{Cl}_{2}(10 \mathrm{~mL})$ at $0{ }^{\circ} \mathrm{C}$ were added methanesulfonyl chloride $(130$ $\mathrm{mg}, 1.14 \mathrm{mmol}$ ) and then triethylamine $(115 \mathrm{mg}, 1.14 \mathrm{mmol})$. The solution was allowed to warm to room temperature and was stirred for 
$2 \mathrm{~h}$. Then the mixture was washed with $10 \% \mathrm{NaHCO}_{3}$ solution, brine and dried over $\mathrm{MgSO}_{4}$. The solvent was removed under reduced pressure and the product was purified on silica gel column chromatography using an EtOAc/hexane mixture $(2 / 8, \mathrm{v} / \mathrm{v})$ to furnish 7 (240 mg, 84\%). ${ }^{1} \mathrm{H} \mathrm{NMR}\left(300 \mathrm{MHz}, \mathrm{CDCl}_{3}\right): \delta 7.49(\mathrm{~d}, J=$ $8.2 \mathrm{~Hz}, 1 \mathrm{H}), 7.27-7.14(\mathrm{~m}, 3 \mathrm{H}), 4.28-4.23(\mathrm{~m}, 2 \mathrm{H}), 4.03-3.99(\mathrm{~m}$, $2 \mathrm{H}), 3.78-3.73(\mathrm{~m}, 2 \mathrm{H}), 2.98(\mathrm{~s}, 3 \mathrm{H}), 2.48(\mathrm{~s}, 3 \mathrm{H}), 2.08-2.03(\mathrm{~m}$ $2 \mathrm{H}), 1.93-1.84(\mathrm{~m}, 2 \mathrm{H})$. ES-MS $m / z$ for $\mathrm{C}_{14} \mathrm{H}_{21} \mathrm{O}_{5} \mathrm{~S}(\mathrm{M}+\mathrm{H})^{+}$, calcd 301.38 , found 301.41 .

4-(5-tert-bButoxycarbonylaminopentynyl)piperidine (8). Compound 14 (995 mg, $2.50 \mathrm{mmol})$ diluted in ethanol $(20 \mathrm{~mL})$, few drops of acetic acid, and $10 \%(\mathrm{w} / \mathrm{w}) \mathrm{PtO}_{2}$ was stirred overnight under 65 psi of hydrogen pressure. The solution was then filtered on a Celite pad that was washed with ethanol. The filtrate was concentrated under vacuo to provide $8(660 \mathrm{mg}$, quantitative yield $)$ that was used without any further purification. ES-MS $m / z$ for $\mathrm{C}_{15} \mathrm{H}_{30} \mathrm{~N}_{2} \mathrm{O}_{2}(\mathrm{M}+$ $\mathrm{H})^{+}$, calcd 271.42, found 271.27 and $293.39(\mathrm{M}+\mathrm{Na})^{+}$.

Benzyl-(4-oxopiperidinyl) Acetate (11). 4-Piperidone 10 (4 g, $26 \mathrm{mmol}$ ) was added to a solution of $\mathrm{NaOH}, 10 \%$, and toluene cooled down at $0{ }^{\circ} \mathrm{C}$. After a few minutes, a solution of benzyl chloroformiate $(4.43 \mathrm{~g}, 26 \mathrm{mmol})$ in toluene was slowly added. The solution was allowed to warm to room temperature and was stirred for $2 \mathrm{~h}$. The solvent was removed under reduced pressure, and the product was diluted in chloroform and washed with water $(2 \times)$, with brine $(2 \times)$ and dried over $\mathrm{MgSO}_{4}$. The solvent was removed under reduced pressure and the product was purified on silica gel column chromatography with EtOAc/heptane to give 11 (5.88 g, 97\%). ${ }^{1} \mathrm{H}$ NMR (300 MHz, $\left.\mathrm{CDCl}_{3}\right): \delta 7.36(\mathrm{~s}, 5 \mathrm{H}), 5.20(\mathrm{~s}, 2 \mathrm{H}), 3.80(\mathrm{t}, J=$ $6.8 \mathrm{~Hz}, 4 \mathrm{H}), 2.46(t, J=6.8 \mathrm{~Hz}, 4 \mathrm{H})$.

Benzyl-(4-\{[(trifluoromethyl)sulfonyl]oxy\}piperidinyl) Acetate (12). To a $-78{ }^{\circ} \mathrm{C}$ cooled solution of $\mathrm{N}$-Cbz-piperidone 11 (1 g, $5 \mathrm{mmol})$ was added LDA $(2.75 \mathrm{~mL}, 5.5 \mathrm{mmol})$. Following agitation for $20 \mathrm{~min}, \mathrm{~N}$-phenyltrifluoromethanesulfonimide $(1.87 \mathrm{~g}, 5.25 \mathrm{mmol})$ was slowly added. The resulting mixture was allowed to warm to room temperature and was stirred for $3 \mathrm{~h}$. The solvent was removed under reduced pressure and the product was purified on silica gel column chromatography using an EtOAc/heptane mixture $(1 / 9, \mathrm{v} / \mathrm{v})$ to furnish $12(1.02 \mathrm{~g}, 56 \%) .{ }^{1} \mathrm{H}$ NMR $\left(300 \mathrm{MHz}, \mathrm{CDCl}_{3}\right): \delta 7.38-7.30$ $(\mathrm{m}, 5 \mathrm{H}), 5.78(\mathrm{~m}, 1 \mathrm{H}), 5.17(\mathrm{~s}, 2 \mathrm{H}), 4.14-4.12(\mathrm{~m}, 2 \mathrm{H}), 3.72(\mathrm{t}, J=$ $6.8 \mathrm{~Hz}, 2 \mathrm{H}), 2.47(\mathrm{~m}, 2 \mathrm{H})$.

4-Pentynylaminecarboxylic Acid tert-Butyl Ester (13). A solution of $\mathrm{LiOH}(1.15 \mathrm{~g}, 48 \mathrm{mmol})$ in $\mathrm{H}_{2} \mathrm{O}(12 \mathrm{~mL})$ was added to a solution of compound $19(4.54 \mathrm{~g}, 16 \mathrm{mmol})$ in THF $(36 \mathrm{~mL})$ and stirred at room temperature for three hours. The solvent was removed under reduced pressure, and the residue was diluted in $\mathrm{CH}_{2} \mathrm{Cl}_{2}$ (40 $\mathrm{mL})$ and washed with $10 \% \mathrm{NaHCO}_{3}$ solution $(2 \times 40 \mathrm{~mL})$ and brine. The organic layer was dried over $\mathrm{Na}_{2} \mathrm{SO}_{4}$, filtered, and concentrated in vacuo to give compound $13(2.75 \mathrm{~g}, 94 \%) .{ }^{1} \mathrm{H}$ NMR $(200 \mathrm{MHz}$, $\left.\mathrm{CDCl}_{3}\right): \delta 4.66($ brs, $1 \mathrm{H}), 3.30-3.20(\mathrm{~m}, 2 \mathrm{H}), 2.30-2.20(\mathrm{~m}, 2 \mathrm{H})$, $2.00-1.96(\mathrm{~m}, 1 \mathrm{H}), 1.80-1.66(\mathrm{~m}, 2 \mathrm{H}), 1.45(\mathrm{~s}, 9 \mathrm{H})$.

4-(5-tert-Butoxycarbonylaminopentynyl)-3,6-dihydro-2 $\mathrm{H}$ pyridinbenzyloxycarbonyl (14). Compound $12(1 \mathrm{~g}, 2.9 \mathrm{mmol})$ was dissolved in THF $(20 \mathrm{~mL})$ in the presence of alkyne $13(795 \mathrm{mg}$, $4.35 \mathrm{mmol}), \mathrm{CuI}(60 \mathrm{mg}, 0.3 \mathrm{mmol}), \mathrm{PdCl}_{2}\left(\mathrm{PPh}_{3}\right)_{2}(210 \mathrm{mg}, 0.3$ $\mathrm{mmol})$, and triethylamine $(460 \mathrm{mg}, 4.35 \mathrm{mmol})$ at room temperature. After $6 \mathrm{~h}$ at room temperature, the mixture was concentrated in vacuo to a residue. Compound $\mathbf{1 4}(940 \mathrm{mg}, 81 \%)$ was isolated by flash chromatography using an EtOAc/heptane mixture (v/v, 1/9). ${ }^{1} \mathrm{H}$ NMR (300 MHz, $\left.\mathrm{CDCl}_{3}\right): \delta 7.38-7.34(\mathrm{~m}, 5 \mathrm{H}), 5.92(\mathrm{~m}, 1 \mathrm{H}), 5.15$ $(\mathrm{s}, 2 \mathrm{H}), 4.69(\mathrm{bs}, 1 \mathrm{H}), 4.03-3.99(\mathrm{~m}, 2 \mathrm{H}), 3.59-3.54(\mathrm{~m}, 2 \mathrm{H}), 3.24-$ $3.22(\mathrm{~m}, 2 \mathrm{H}), 2.39-2.35(\mathrm{~m}, 2 \mathrm{H}), 2.32-2.30(\mathrm{~m}, 2 \mathrm{H}), 1.75-1.72(\mathrm{~m}$, $2 \mathrm{H}), 1.44(\mathrm{~s}, 9 \mathrm{H})$.

Ethyl Oxoisocynate Acetate (16). The oxalyl chloride (66.7 $\mathrm{mmol})$ was added to a suspension of ethyl oxamate $15(6.5 \mathrm{~g}, 55.6$ $\mathrm{mmol})$ in $\mathrm{CH}_{2} \mathrm{Cl}_{2}(80 \mathrm{~mL})$ and refluxed overnight. The solvent was reduced in vacuo to isocyanate $\mathbf{1 6}$ that was used without any further purification (7.15 g, 90\%).

tert-Butyl(oxo)ethyl Acetate Carbamate (17). A solution of tert-butanol $(3.75 \mathrm{~g}, 51 \mathrm{mmol})$ in toluene $(20 \mathrm{~mL})$ was added to a solution of isocyanate $16(7.17 \mathrm{~g}, 50 \mathrm{mmol})$ in toluene $(50 \mathrm{~mL})$ and heated at $40{ }^{\circ} \mathrm{C}$ overnight. The solvent was concentrated in vacuo to a residue that was purified by flash chromatography $\left(\mathrm{EtOAc} / \mathrm{CH}_{2} \mathrm{Cl}_{2}, 5 /\right.$ 95, v/v) to give $17(7.82 \mathrm{~g}, 72 \%) .{ }^{1} \mathrm{H}$ NMR $\left(200 \mathrm{MHz}, \mathrm{CDCl}_{3}\right): \delta$ $4.37(\mathrm{q}, J=6.9 \mathrm{~Hz}, 2 \mathrm{H}), 1.51(\mathrm{~s}, 9 \mathrm{H}), 1.38(\mathrm{t}, J=6.9 \mathrm{~Hz}, 3 \mathrm{H})$.

4-Pentynylamine(oxo)ethyl Acetate Carboxylic Acid tertButyl Ester (19). A solution of DEAD (3.32 g, $19 \mathrm{mmol})$ in THF (10 $\mathrm{mL}$ ) was added dropwise to a solution of compound 17 (4.16 g, 19 $\mathrm{mmol})$, 4-pentynol 18 (1.6 g, $19 \mathrm{mmol})$, and triphenylphosphine (4.99 $\mathrm{g}, 19 \mathrm{mmol})$ in THF $(15 \mathrm{~mL})$. The solution was stirred overnight at room temperature and concentrated in vacuo to a residue that was purified by flash chromatography (heptane/EtOAc, 9/1, v/v) to give $19(4.57 \mathrm{~g}, 85 \%) .{ }^{1} \mathrm{H}$ NMR $\left(200 \mathrm{MHz}, \mathrm{CDCl}_{3}\right): \delta 4.33(\mathrm{q}, J=6.9 \mathrm{~Hz}$, $2 \mathrm{H}), 3.80-3.75(\mathrm{~m}, 2 \mathrm{H}), 2.26-2.21(\mathrm{~m}, 2 \mathrm{H}), 1.98-1.96(\mathrm{~m}, 1 \mathrm{H})$, $1.86-1.77(\mathrm{~m}, 2 \mathrm{H}), 1.52(\mathrm{~s}, 9 \mathrm{H}), 1.35(\mathrm{t}, J=6.9 \mathrm{~Hz}, 3 \mathrm{H})$.

Para-LRB- $\boldsymbol{n}$-butyl (20). To a solution of lissamine rhodamine $\mathrm{B}$ sulfonyl chloride $(100 \mathrm{mg}, 173 \mu \mathrm{mol})$ in $\mathrm{CH}_{2} \mathrm{Cl}_{2}$ was added $n$ butylamine ( $86 \mu \mathrm{L}, 860 \mu \mathrm{mol})$ in the presence of triethylamine $(119.5$ $\mu \mathrm{L}, 860 \mu \mathrm{mol})$. The resulting solution was stirred at room temperature overnight (Scheme 5). Following concentration under reduced pressure, the para isomer $(24.4 \mathrm{mg}, 23 \%)$ was isolated by preparative RP-HPLC on a C18 Symmetry Shield column $(19 \mathrm{~mm} \times 300 \mathrm{~mm})$ using a linear gradient of eluent $\mathrm{B}(5-100 \% \mathrm{~B}$ in $30 \mathrm{~min}$, flow rate of $\left.10 \mathrm{~mL} \cdot \mathrm{min}^{-1}\right)$ in eluent $\mathrm{A}\left(100 \% \mathrm{H}_{2} \mathrm{O}, 0.1 \% \mathrm{TFA}, \mathrm{v} / \mathrm{v}\right)$. Fractions of interest were pooled, concentrated, and further checked for purity by analytical RP-HPLC on an Agilent Eclipse XDB-C18 column $(4.6 \mathrm{~mm}$ $\times 150 \mathrm{~mm}$ ), using a linear gradient from $5 \%$ to $100 \%$ solvent B in 15 $\min$ (flow rate of $1 \mathrm{~mL} / \mathrm{min}$ ). RP-HPLC purity: $>98 \%$; $t_{\mathrm{R}}=11.5 \mathrm{~min}$. ${ }^{1} \mathrm{H}$ NMR (DMSO- $\left.d_{6}, 500 \mathrm{MHz}\right): \delta 8.41(\mathrm{~s}, 1 \mathrm{H}), 7.92(\mathrm{~d}, J=7.5 \mathrm{~Hz}$, $1 \mathrm{H}), 7.88(\mathrm{t}, J=5.6 \mathrm{~Hz}, 1 \mathrm{H}), 7.47(\mathrm{~d}, J=8.0,1 \mathrm{H}), 7.05-6.93(\mathrm{~m}$, $6 \mathrm{H}), 7.35-7.30(\mathrm{~m}, 2 \mathrm{H}), 3.65-3.63(\mathrm{~m}, 8 \mathrm{H}), 2.86(\mathrm{q}, J=6.3 \mathrm{~Hz}$, $2 \mathrm{H}), 1.48-1.39(\mathrm{~m}, 2 \mathrm{H}), 1.32-1.19(\mathrm{~m}, 14 \mathrm{H}), 0.85(\mathrm{t}, J=7.2 \mathrm{~Hz}$, $3 \mathrm{H}) .{ }^{13} \mathrm{C}$ NMR (DMSO- $\left.d_{6}, 100 \mathrm{MHz}\right): \delta 155.9,156.5,154.4,147.5$, 141.1, 132.3, 132.0, 130.0, 125.9, 125.1, 113.0, 94.8, 44.6, 41.7, 30.5, 18.6, 12.9, 11.9. ES-MS $m / z$ for $\mathrm{C}_{31} \mathrm{H}_{39} \mathrm{~N}_{3} \mathrm{O}_{6} \mathrm{~S}_{2}(\mathrm{M}+\mathrm{H})^{+}$, calcd 614.23, found 614.20.

Construction of EGFP-Fused Muscarinic M1 Receptors and Cell Expression. Fluorescent chimera of the human M1 receptor was essentially as previously reported. ${ }^{27}$ EGFP was fused, via an identical short linker, to the full-length (EGFP-wthM1) or truncated by 11 $(\operatorname{EGFP}(\Delta 17) \mathrm{hM} 1)$ or 17 residues $(\operatorname{EGFP}(\Delta 17) \mathrm{hM} 1)$ receptor $\mathrm{N}$ terminus. The exchange of the long linker (referred to $\mathrm{L}$ in the previously described $\operatorname{EGFP}_{\mathrm{L}}(\Delta 11) \mathrm{hM} 1$ chimera) for a short one was done through ligation, into a Bluescript KS+ vector, of the NotI-BglII (signal peptide-EGFP sequence-short linker) and BglII-XhoI (hM1 sequence with a truncated $\mathrm{N}$ tail taken from the $\operatorname{EGFP}_{\mathrm{L}}(\Delta 11) \mathrm{hM} 1$ construct) fragments, as earlier defined. ${ }^{27}$ The final construct (NotIXhoI insert) was subcloned into the pCep4 vector for expression into eukaryotic cells and sequenced before use. Transfection of HEK 293 cells by calcium phosphate precipitation and hygromycin-B selection proceeded as previously detailed. ${ }^{27}$ Cells were grown in minimal essential medium supplemented with $10 \%$ fetal calf serum, $2 \mathrm{mM}$ glutamine, penicillin $(100 \mathrm{U} / \mathrm{mL})$, and streptomycin $(100 \mu \mathrm{g} / \mathrm{mL})$ and incubated at $37{ }^{\circ} \mathrm{C}$ in a $5 \% \mathrm{CO}_{2}$ humidified atmosphere.

Functional Calcium Responses. Agonist-evoked increases in intracellular calcium were monitored in HEK cells, with stable expression of the various receptor constructs. Adherent cells were loaded with $5 \mu \mathrm{M}$ Indo- $1 \mathrm{AM}$ for $45 \mathrm{~min}$ at $37^{\circ} \mathrm{C}$, harvested by rapid $0.05 \%$ trypsin $/ 0.02 \%$ EDTA treatment $(\mathrm{wt} / \mathrm{v})$, washed, and finally suspended $\left(10^{6}\right.$ cells $\left./ \mathrm{mL}\right)$ in Hepes buffer $(10 \mathrm{mM}$ Hepes, $137.5 \mathrm{mM}$ $\mathrm{NaCl}, 1.25 \mathrm{mM} \mathrm{MgCl}_{2}, 1.25 \mathrm{mM} \mathrm{CaCl}_{2}, 6 \mathrm{mM} \mathrm{KCl}, 10 \mathrm{mM}$ glucose, 1 $\mathrm{mg} / \mathrm{mL}$ bovine serum albumin; $\mathrm{pH}$ 7.4).

Calcium signals were recorded over time as an increase in fluorescence emission at $400 \mathrm{~nm}$, with excitation set at $338 \mathrm{~nm}$. Inhibitory compounds were preincubated with cells for $5 \mathrm{~min}$ before carbachol challenge. After baseline correction, peak amplitudes were normalized to maximal fluorescence levels determined in the presence of $20 \mu \mathrm{M}$ digitonine. Data for M1-transfected cells are expressed, as appropriate, as a percentage of the maximal response to $10 \mu \mathrm{M}$ carbachol or of a control response to $0.5 \mu \mathrm{M}$ carbachol obtained in the absence of inhibitor. Unless otherwise stated, calcium signals were 
recorded at $20{ }^{\circ} \mathrm{C}$ from M1-overexpressing cells and at $37{ }^{\circ} \mathrm{C}$ when using nontransfected HEK cells.

Measurements of Receptor Expression Levels. HEK cells stably expressing the various hM1 constructs were checked for receptor density through quantification of specific binding at a single saturating concentration of $\left[{ }^{3} \mathrm{H}\right] \mathrm{QNB}\left(0.3 \mathrm{nM}, 2 \mathrm{~h}\right.$ at $\left.37{ }^{\circ} \mathrm{C}\right)$ or $\left[{ }^{3} \mathrm{H}\right]$ NMS $\left(0.75 \mathrm{nM}, 2 \mathrm{~h}\right.$ at $\left.20{ }^{\circ} \mathrm{C}\right)$ or determination of $B_{\max }$ values from $\left[{ }^{3} \mathrm{H}\right]$ NMS $(0.02-1.2 \mathrm{nM})$ saturation experiments conducted on $\operatorname{EGFP}(\Delta 17) \mathrm{hM} 1$ cells. $K_{\mathrm{d}}$ values for $\left[{ }^{3} \mathrm{H}\right] \mathrm{QNB}$ and $\left[{ }^{3} \mathrm{H}\right] \mathrm{NMS}$ binding to hM1 receptors are $50^{27}$ and $95 \mathrm{pM}$, respectively.

Alkylation of Muscarinic Receptors by Propylbenzilylcholine Mustard. A $50 \mu \mathrm{M}$ solution of PrBCM in Hepes buffer (deprived of BSA) was incubated at $37^{\circ} \mathrm{C}$ for $30 \mathrm{~min}$ to allow cyclization of the compound into the aziridinium ion. Thereafter, activated PrBCM was added to $\operatorname{EGFP}(\Delta 17) \mathrm{hM} 1$ cells $\left(2 \times 10^{6}\right.$ cells $\left./ \mathrm{mL}\right)$ to a final $30 \mathrm{nM}$ concentration and allowed to incubate for $40 \mathrm{~min}$ at $37^{\circ} \mathrm{C}$. Buffer without PrBCM was added to control cells. After a 3-fold dilution of the medium with Hepes buffer at $20{ }^{\circ} \mathrm{C}$, centrifugation at $1000 \mathrm{rpm}$ for $5 \mathrm{~min}$, and supernatant removal, cell pellets were washed by resuspension in $200 \mathrm{vol}$ of buffer and centrifuged again. Final cell suspensions, at an appropriate density, were kept on ice until further use.

$\left[{ }^{3} \mathrm{H}\right] N M S$ Binding Assays. Nearly confluent cells were harvested using a Versene solution (PBS + 5 mM EDTA), washed with Hepes buffer, and pelleted by centrifugation at $1000 \mathrm{rpm}$ for $5 \mathrm{~min}$ before suspension at an appropriate dilution. $\left[{ }^{3} \mathrm{H}\right] \mathrm{NMS}$ binding was carried out in Hepes buffer at $20^{\circ} \mathrm{C}$, using whole cells stably expressing the $\operatorname{EGFP}(\Delta 17) \mathrm{hM} 1$ receptor. Separation of bound from free radioactivity was achieved by filtration through Whatman GF/B glass-fiber filters presoaked with $0.2 \%$ polyethyleneimine. Tubes and filters were rinsed three times with ice-cold $25 \mathrm{mM}$ Tris- $\mathrm{HCl}$ buffer ( $\mathrm{pH}$ 7.4) before determination of bound radioactivity by liquid scintillation counting. Nonspecific binding was determined in the presence of $10 \mu \mathrm{M}$ atropine.

Competition-type experiments were performed on $\operatorname{EGFP}(\Delta 17)$ hM1 cells (typically 60000 per assay) with $0.1 \mathrm{nM}\left[{ }^{3} \mathrm{H}\right] \mathrm{NMS}$, unless otherwise stated, and various concentrations of test compounds. Incubation lasted for $22 \mathrm{~h}$ at $20^{\circ} \mathrm{C}$ in a $1 \mathrm{~mL}$ final volume. Under such conditions, total bound $\left[{ }^{3} \mathrm{H}\right] \mathrm{NMS}$ did not exceed $10 \%$ of total added radioligand and nonspecific binding was low (less than 5\% of total binding). When adding drugs diluted in DMSO, we verified that the highest solvent concentration in the incubation medium $(1 \%, \mathrm{v} / \mathrm{v}) \mathrm{did}$ not affect tracer binding. Data are expressed as $B / B_{0}$ ratios, where $B_{0}$ (set as 1 ) and $B$ refer to specific $\left[{ }^{3} \mathrm{H}\right]$ NMS binding in the absence and the presence of competitors, respectively.

Dissociation-type experiments were performed at $25{ }^{\circ} \mathrm{C}$ using $\operatorname{EGFP}(\Delta 17) \mathrm{hM} 1$ cells, according to a previously described protocol. ${ }^{50}$ A 100 -fold concentrated cell suspension $(60000$ cells per $10 \mu \mathrm{L})$ was preincubated for $30 \mathrm{~min}$ with $3 \mathrm{nM}\left[{ }^{3} \mathrm{H}\right] \mathrm{NMS}$ in the absence (total binding) or the presence (nonspecific binding) of $10 \mu \mathrm{M}$ atropine, then kept on ice. The $10 \mu \mathrm{L}$ aliquots of both prelabeled cell batches were added to a series of test tubes filled with $1 \mathrm{~mL}$ Hepes buffer (at $25{ }^{\circ} \mathrm{C}$ ) containing $10 \mu \mathrm{M}$ atropine alone or combined with a test compound at various concentrations. At given dissociation time points (usually set between 1 and $3\left[{ }^{3} \mathrm{H}\right] \mathrm{NMS}$ dissociation half-lives), the reaction was stopped by rapid filtration, allowing the quantification of residual specific $\left[{ }^{3} \mathrm{H}\right]$ NMS binding ( $B$ values). Specific $\left[{ }^{3} \mathrm{H}\right]$ NMS binding a time $0\left(B_{0}\right)$ was determined in parallel through direct filtration of extemporaneously diluted (in ice-cold buffer) prelabeled cell samples $(10 \mu \mathrm{L})$. All off-rate experiments, presented as $B / B_{0}$ versus dissociation time, fitted a monoexponential time course with a characteristic $k_{\text {off }}$ rate constant.

Fluorescence Resonance Energy Transfer (FRET) Based Binding Assays. Data were collected from cell suspensions $\left(10^{6}\right.$ cells $/ \mathrm{mL}$ ) placed in a $1 \mathrm{~mL}$ quartz cuvette (with magnetic stirring) maintained at $20^{\circ} \mathrm{C}$, using a Fluorolog 2 spectrofluorimeter (Horiba Jobin-Yvon). Specific binding of fluorescent tracers to $\operatorname{EGFP}(\Delta 17)$ $\mathrm{hM1}$ expressing cells was monitored, in real-time or at equilibrium, through atropine-dependent variations in EGFP emission at $510 \mathrm{~nm}$ (excitation set at $470 \mathrm{~nm}$ ).
Equilibrium binding assays consisted of incubating cells with increasing (saturation experiments) or fixed (competition experiments) concentrations of a fluorescent tracer, in the absence or the presence of various concentrations of unlabeled drugs. Incubation proceeded for $4 \mathrm{~h}$ at $20{ }^{\circ} \mathrm{C}$ (unless otherwise stated) in test tubes (1 $\mathrm{mL}$ final volume) before transfer of the medium into the quartz cuvette for fluorescent readouts of EGFP emission.

Time-based monitoring of tracer binding consisted of continuous fluorescence recordings of $\operatorname{EGFP}(\Delta 17) \mathrm{hM} 1$ cells before and following the addition of the fluorescent probe $(4 \mu \mathrm{L}$ of a 250 -fold concentrated DMSO stock). Once equilibrium was reached, tracer dissociation was initiated by adding atropine $(20 \mu \mathrm{M})$, alone or in the presence of other compounds, to the cell suspension and fluorescence was recorded over time until full recovery of EGFP emission.

The FRET signal associated with specific binding of a fluorescent probe to M1 receptors was defined as the difference in fluorescence levels of cells incubated with the tracer alone or together with $20 \mu \mathrm{M}$ atropine.

Molecular Modeling. Sequence alignment and homology modeling were performed using MOE 2009.10 with default settings (Chemical Computing Group Inc., Montreal, Canada). Constraints were manually set to guide the sequence alignment in order to avoid the introduction of gap in the TM regions and to fix the disulfide bridge between Cys98 in TM3 and Cys178 in ECL2 (sequence alignment is provided in Supporting Information Figure S3). A first model of the full M1 receptor (residues Gly29-Cys435) was obtained by homology to the dopamine D3 template (PDB entry 3PBL, chain A). This model was edited using SYBYL-X, version 1.3 (Tripos, Inc., St. Louis, MO, U.S.), to replace the ECL2 loop by fragments extracted from the structures of the human $\beta 2$ adrenergic (ADRB2) and adenosine 2A (AA2A) receptors. More precisely, the Leu162-Gln177 segment of the M1 model was replaced by the Gln170-Cys190 segment of the A chain of the 2RH1 PDB file and the Cys178-Pro187 segment of the M1 model was replaced by the Cys166-Asn175 segment of the A chain of 3EML PDB file. The chimeric structure constituted the template for the second round of M1 homology modeling using MOE 2009.10. The third intracellular loop (ICL3) of the M1 was removed using SYBYL-X, version 1.3, and the termini were capped with ACE and NME residues. The M1 model was energy minimized using AMBER9 (University of California, San Francisco, CA, USA) (Supporting Information Figure S2).

The 3D structures of AC-42 and para-LBR-AC42 were generated using Corina, version 3.1 (Molecular Network GmbH, Erlangen, Germany), from a 2D sketch drawn using Marvinsketch (MarvinBeans, version 5.3.01, ChemAxon, Budapest, Hungary). Ternary amine groups were assigned a positive charge, sulfate groups a negative charge. The flexible alignment of molecules was performed using SurflexSim, version 2.6 (BioPharmics LCC, San Mateo, CA, U.S.).

\section{ASSOCIATED CONTENT}

\section{Supporting Information}

Figure S1 showing normalized absorption and emission spectra of EGFP and para-LRB-AC42 in Hepes buffer; Figure S2 showing structural variation of the M1 receptor; Figure S3 showing sequence alignment for M1 homology modeling; procedures for solubility measurements, estimation of donoracceptor distances through FRET, and biological data analyses. This material is available free of charge via the Internet at http://pubs.acs.org.

\section{AUTHOR INFORMATION}

\section{Corresponding Author}

*Phone: +33 3688547 38. Fax: +33 3688548 29. E-mail: brigitte.ilien@unistra.fr.

\section{Present Addresses}

${ }^{\S}$ Quintiles, Parc d'Innovation, 67404 Illkirch, France. 
"Drug Discovery Biology Laboratory, Department of Pharmacology, Monash University, Clayton, Victoria 3800, Australia. Notes

The authors declare no competing financial interest.

\section{ACKNOWLEDGMENTS}

We thank Dr. T. Spalding, ACADIA Pharmaceuticals Inc. (San Diego, CA, U.S.) and Pr. A. Christopoulos (Monash University, Victoria, Australia) for the generous gift of AC-42. Dr. N. Birdsall (NIMR, London, U.K.) kindly provided us with propylbenzilylcholine mustard. We are grateful to Patrick Wehrung and Cyril Antheaume for NMR, HR-MS, and HPLC analyses and to Patrick Gizzi (TechMed platform; UMR 7242 CNRS, Illkirch, France) for solubility measurements. The skillful technical assistance of Stéphanie Riché and Valérie Utard was greatly appreciated.

This work was supported in part by CNRS, INSERM, and the Université de Strasbourg.

S.B.D. was a recipient of a grant from the Association Nationale de la Recherche Technique (Convention CIFRE 564/2005 with Prestwick Chemical).

C.V. was supported by a fellowship from the Ministère de l'Education Nationale, de l'Enseignement Supérieur et de la Recherche (MENSER).

\section{ABBREVIATIONS USED}

AC-42, 4-n-butyl-1-[4-(2-methylphenyl)-4-oxo-1-butyl]piperidine hydrogen chloride; BSA, bovine serum albumin; ECL, extracellular loop; EGFP, enhanced green fluorescent protein; FRET, fluorescence resonance energy transfer; HEK, human embryonic kidney; hM1, human M1 muscarinic receptor subtype; LRB, lissamine rhodamine $\mathrm{B}$; $\mathrm{mAChR}$, muscarinic cholinergic receptor; NDMC, N-desmethylclozapine; NMS, $\mathrm{N}$-methylscopolamine; PrBCM, propylbenzilylcholine mustard; QNB, quinuclidinyl benzilate; TM, transmembrane domain

\section{REFERENCES}

(1) Eglen, R. M. Muscarinic receptor subtype pharmacology and physiology. Prog. Med. Chem. 2005, 43, 105-136.

(2) Wess, J.; Eglen, R. M.; Gautam, D. Muscarinic acetylcholine receptors: mutant mice provide new insights for drug development. Nat. Rev. Drug Discovery 2007, 6, 721-733.

(3) Digby, G. J.; Shirey, J. K.; Conn, P. J. Allosteric activators of muscarinic receptors as novel approaches for treatment of CNS disorders. Mol. BioSyst. 2010, 6, 1345-1354.

(4) Birdsall, N. J. M.; Lazareno, S. Allosterism at muscarinic receptors: ligands and mechanisms. Mini-Rev. Med. Chem. 2005, 33, 523-543.

(5) De Amici, M.; Dallanoce, C.; Holzgrabe, U.; Tränkle, C.; Mohr, $\mathrm{K}$. Allosteric ligands for $\mathrm{G}$ protein-coupled receptors: a novel strategy with attractive therapeutic opportunities. Med. Res. Rev. 2010, 30, 463-549.

(6) May, L. T.; Leach, K.; Sexton, P. M.; Christopoulos, A. Allosteric modulation of G protein-coupled receptors. Annu. Rev. Pharmacol. Toxicol. 2007, 47, 14.1-14.51.

(7) Maillet, E. L.; Pellegrini, N.; Valant, C.; Bucher, B.; Hibert, M.; Bourguignon, J.-J.; Galzi, J.-L. A novel, conformation-specific allosteric inhibitor of the tachykinin NK2 receptor (NK2R) with functionally selective properties. FASEB J. 2007, 21, 2124-2134.

(8) Ehlert, F. J. Estimation of the affinities of allosteric ligands using radioligand binding and pharmacological null methods. Mol. Pharmacol. 1988, 35, 187-194.

(9) Sur, C.; Mallorga, P. J.; Wittmann, M.; Jacobson, M. A.; Pascarella, D.; Williams, J. B.; Brandish, P. E.; Pettibone, D. J.;
Scolnick, E. M.; Conn, P. J. N-Desmethylclozapine, an allosteric agonist at muscarinic M1 receptor, potentiates $N$-methyl-D-aspartate receptor activity. Proc. Natl. Acad. Sci. U.S.A. 2003, 100, 13674-13679.

(10) Spalding, T. A.; Trotter, C.; Skjaerbaek, N.; Messier, T. L.; Currier, E. A.; Burstein, E. S.; Li, D.; Hacksell, U.; Brann, M. R. Discovery of an ectopic activation site on the M1 muscarinic receptor. Mol. Pharmacol. 2002, 61, 1297-1302.

(11) Langmead, C. J.; Fry, V. A. H.; Forbes, I. T.; Branch, C. L.; Christopoulos, A.; Wood, M. D.; Herdon, H. J. Probing the molecular mechanism of interaction between 4-n-butyl-1-[4-(2-methylphenyl)-4oxo-1-butyl]-piperidine (AC-42) and the muscarinic M1 receptor: direct pharmacological evidence that AC-42 is an allosteric agonist. Mol. Pharmacol. 2006, 69, 236-246.

(12) Spalding, T. A.; Ma, J. N.; Ott, T. R.; Friberg, M.; Bajpai, A.; Risso Bradley, S.; Davis, R. E.; Brann, M. R.; Burstein, E. S. Structural requirements of transmembrane domain 3 for activation by the M1 muscarinic receptor agonists AC-42, AC-260584, clozapine, and $\mathrm{N}$ desmethylclozapine: evidence for three distinct modes of receptor activation. Mol. Pharmacol. 2006, 70, 1974-1983.

(13) Langmead, C. J.; Austin, N. E.; Branch, C. L.; Brown, J. T.; Buchanan, K. A.; Davies, C. H.; Forbes, I. T.; Fry, V. A. H.; Hagan, J. J.; Herdon, H. J.; Jones, G. A.; Jeggo, R.; Kew, J. N. C.; Mazzali, A.; Melarange, R; et al. Characterization of a CNS penetrant, selective M1 muscarinic receptor agonist, 77-LH-28-1. Br. J. Pharmacol. 2008, 154, 1104-1115.

(14) Jones, C. K.; Brady, A. E.; Davis, A. A.; Xiang, Z.; Bubser, M.; Tantawy, M. N.; Kane, A. S.; Bridges, T. M.; Kennedy, J. P.; Bradley, S. R.; Peterson, T. E.; Ansari, M. S.; Baldwin, R. M.; et al. Novel selective allosteric activator of the M1 muscarinic acetylcholine receptor regulates amyloid processing and produces antipsychotic-like activity in rats. J. Neurosci. 2008, 28, 10422-10433.

(15) Sams, A. G.; Hentzer, M.; Mikkelsen, G. K.; Larsen, K.; Bundgaard, C.; Plath, N.; Christofferson, C. T.; Bang-Andersen, B. Discovery of $\mathrm{N}$-\{1-[3-(3-oxo-2,3-dihydrobenzo[1,4] oxazin-4-yl)propyl]piperidin-4-yl\}-2-phenylacetamide (Lu AE51090): an allosteric muscarinic M1 receptor agonist with unprecedented selectivity and precognitive potential. J. Med. Chem. 2010, 53, 6386-6397.

(16) Lebois, E. P.; Bridges, T. M.; Lewis, L. M.; Dawson, E. S.; Kane, A. S.; Xiang, Z.; Jadhav, S.; Yin, H.; Kennedy, J. P.; Meiler, J.; Niswender, C. M.; Jones, C. K.; Conn, P. J.; Weaver, C. D.; Lindsley, C. W. Discovery and characterization of novel subtype-selective allosteric agonists for the investigation of $\mathrm{M} 1$ receptor function in the central nervous system. ACS Chem. Neurosci. 2010, 1, 104-121.

(17) Bradley, S. R.; Lameh, J.; Ohrmund, L.; Son, T.; Bajpai, A.; Nguyen, D.; Friberg, M.; Burstein, E. S.; Spalding, T. A.; Ott, T. R.; Schiffer, H. H.; Tabatabaei, A.; McFarland, K.; Davis, R. E.; Bonhaus, D. W. AC-260584, an orally bioavailable M1 muscarinic receptor allosteric agonist, improves cognitive performance in an animal model. Neuropharmacology 2010, 58, 365-373.

(18) Buchanan, K. A.; Petrovic, M. M.; Chamberlain, S. E. L.; Marrion, N. V.; Mellor, J. R. Facilitation of long-term potentiation by muscarinic M1 receptors is mediated by inhibition of SK channels. Neuron 2010, 68, 948-963.

(19) Thomas, R. L.; Mistry, R.; Langmead, C. J.; Wood, M. D.; Challiss, R. A. J. G protein coupling and signalling pathway activation by M1 muscarinic acetylcholine receptor orthosteric and allosteric agonists. J. Pharmacol. Exp. Ther. 2008, 327, 365-374.

(20) Thomas, R. L.; Langmead, C. J.; Wood, M. D.; Challiss, R. A. J. Contrasting effects of allosteric and orthosteric agonists on M1 muscarinic acetylcholine receptor internalization and down-regulation. J. Pharmacol. Exp. Ther. 2009, 331, 1086-1095.

(21) Davis, A. A.; Heilman, C. J.; Brady, A. E.; Miller, N. R.; Fuerstenau-Sharp, M.; Hanson, B. J.; Lindsley, C. W.; Conn, P. J.; Lah, J. J.; Levey, A. I. Differential effects of allosteric M1 muscarinic acetylcholine receptor agonists on receptor activation, arrestin 3 recruitment, and receptor downregulation. ACS Chem. Neurosci. 2010, $1,542-551$.

(22) Ballesteros, J. A.; Weinstein, H. Integrated methods for the construction of three dimensional models and computational probing 
of structure-function relationships in G-protein coupled receptors. Methods Neurosci. 1995, 25, 366-428.

(23) Lebon, G.; Langmead, C. J.; Tehan, B. G.; Hulme, E. C. Mutagenic mapping suggests a novel binding mode for selective agonists of M1 muscarinic acetylcholine receptors. Mol. Pharmacol. 2009, 75, 331-341.

(24) Avlani, V. A.; Langmead, C. J.; Guida, E.; Wood, M. D.; Tehan, B. G.; Herdon, H. J.; Watson, J. M.; Sexton, P. M.; Christopoulos, A. Orthosteric and allosteric modes of interaction of novel selective agonists of the M1 muscarinic acetylcholine receptor. Mol. Pharmacol. 2010, 78, 94-104.

(25) Gregory, K. J.; Hall, N. E.; Tobin, A. B.; Sexton, P. M.; Christopoulos, A. Identification of orthosteric and allosteric site mutations in M2 muscarinic acetylcholine receptors that contribute to ligand-selective signalling bias. J. Biol. Chem. 2010, 285, 7459-7474.

(26) Jacobson, M. A.; Kreatsoulas, C.; Pascarella, D. M.; O’Brien, J. A.; Sur, C. The M1 muscarinic receptor allosteric agonists AC-42 and 1-[1'-(2-methylbenzyl)-1,4'-bipiperidin-4-yl]-1,3-dihydro-2H-benzimidazol-2-one bind to a unique site distinct from the acetylcholine orthosteric site. Mol. Pharmacol. 2010, 78, 648-657.

(27) Ilien, B.; Franchet, C.; Bernard, P.; Morisset, S.; Weill, C. O.; Bourguignon, J.-J.; Hibert, M.; Galzi, J.-L. Fluorescence resonance energy transfer to probe human M1 muscarinic receptor structure and drug binding properties. J. Neurochem. 2003, 85, 768-778.

(28) Ilien, B.; Glasser, N.; Clamme, J.-P.; Didier, P.; Piemont, E.; Chinnappan, R.; Daval, S. B.; Galzi, J.-L.; Mely, Y. Pirenzepine promotes the dimerization of muscarinic M1 receptors through a three-step binding process. J. Biol. Chem. 2009, 284, 19533-19543.

(29) Vanover, K. E.; Veinbergs, I.; Davis, R. E. Antipsychotic-like behavioural effects and cognitive enhancement by a potent and selective muscarinic M1 receptor agonist, AC-260584. Behav. Neurosci. 2008, 122, 570-575.

(30) Astles, P. C.; Brealey, C.; Brown, T. J.; Facchini, V.; Handscombe, C.; Harris, N. V.; McCarthy, C.; McLay, I. M.; Porter, B.; Roach, A. G.; Sargent, C.; Smith, C.; Walsh, R. J. A. Selective endothelin A receptor antagonists: discovery and structure-activity relationships of a series of 4-phenoxybutanoic acid derivatives. J. Med. Chem. 1998, 41, 2732-2744.

(31) Ward, H. R.; Sherman, P. D. Carbonyl participation in the solvolysis of ketone derivatives. The observation and isolation of intermediates. J. Am. Chem. Soc. 1968, 90, 3812-3817.

(32) Wustrow, D. J.; Wise, L. D. Coupling of arylboronic acids with a partially reduced pyridine derivative. Synthesis 1991, 11, 993-995.

(33) Scott, W. J.; Pena, M. R.; Sward, K.; Stoessel, S. J.; Stille, J. K. Palladium-catalyzed olefination of vinyl triflates. J. Org. Chem. 1985, 50, 2302-2308.

(34) Crisp, G. T.; Jiang, Y.-L.; Pullman, P. J.; De Savi, C. Elaboration of the side-chain of amino acid derivatives by palladium catalysed couplings. Tetrahedron 1997, 53, 17489-17500.

(35) Berrée, F.; Michelot, G.; Le Corre, M. N-Boc ethyl oxamate: a new nitrogen nucleophile for use in Mitsunobu reactions. Tetrahedron Lett. 1998, 39, 8275-8276.

(36) Bonnet, D.; Riche, S.; Loison, S.; Dagher, R.; Frantz, M. C.; Boudier, L.; Rahmeh, R.; Mouillac, B.; Haiech, J.; Hibert, M. Solidphase organic tagging resins for labeling biomolecules by 1,3-dipolar cycloaddition: application to the synthesis of a fluorescent nonpeptidic vasopressin receptor ligand. Chem.-Eur. J. 2008, 14, 62476254.

(37) Corrie, J. E. T.; Davis, C. T.; Eccleston, J. F. Chemistry of sulforhodamine-amine conjugates. Bioconjugate Chem. 2001, 12, 186194.

(38) Tahtaoui, C.; Parrot, I.; Klotz, P.; Guillier, F.; Galzi, J.-L.; Hibert, M.; Ilien, B. Fluorescent pirenzepine derivatives as potential bitopic ligands of the human M1 muscarinic receptor. J. Med. Chem. 2004, 47, $4300-4315$.

(39) Weill, C.; Galzi, J. L.; Chasserot-Golaz, S.; Goeldner, M.; Ilien, B. Functional characterization and potential applications for enhanced green fluorescent protein- and epitope-fused human M1 muscarinic receptors. J. Neurochem. 1999, 73, 791-801.
(40) Lazareno, S.; Birdsall, N. J. M. Detection, quantitation, and verification of allosteric interactions of agents with labeled and unlabeled ligands at $G$ protein-coupled receptors: interactions of strychnine and acetylcholine at muscarinic receptors. Mol. Pharmacol. 1995, 48, 362-378.

(41) Jakubik, J.; Bacakova, L.; El-Fakahany, E. E.; Tucek, S. Positive cooperativity of acetylcholine and other agonists with allosteric ligands on muscarinic acetylcholine receptors. Mol. Pharmacol. 1997, 52, 172179.

(42) Matsui, H. S.; Lazareno, S.; Birdsall, N. J. M. Probing of the location of the allosteric site on $\mathrm{m} 1$ muscarinic receptors by sitedirected mutagenesis. Mol. Pharmacol. 1995, 47, 88-98.

(43) Lazareno, S.; Popham, A.; Birdsall, N. J. M. Allosteric interactions of staurosporine and other indolocarbazoles with $\mathrm{N}$ $\left[\right.$ methyl- $\left.{ }^{3} \mathrm{H}\right]$ scopolamine and acetylcholine at muscarinic receptor subtypes: identification of a second allosteric site. Mol. Pharmacol. 2000, 58, 194-207.

(44) Gharagozloo, P.; Lazareno, S.; Popham, A.; Birdsall, N. J. M. Allosteric interactions of quaternary strychnine and brucine derivatives with muscarinic acetylcholine receptors. J. Med. Chem. 1999, 42, 438445 .

(45) Fruchart-Gaillard, C.; Mourier, G.; Marquer, C.; Ménez, A.; Servent, D. Identification of various allosteric interaction sites on M1 muscarinic receptor using ${ }^{125} \mathrm{I}-\mathrm{Met} 35$-oxidized muscarinic toxin 7. Mol. Pharmacol. 2006, 69, 1641-1651.

(46) Kostenis, E.; Mohr, K. Two-point kinetic experiments to quantify allosteric effects on radioligand dissociation. Trends Pharmacol. Sci. 1996, 17, 280-283.

(47) Kurtenbach, E.; Curtis, C. A. M.; Pedder, E. K.; Aitken, A.; Harris, A. C. M.; Hulme, E. C. Muscarinic acetylcholine receptors. Peptide sequencing identifies residues involved in antagonist binding and disulfide bond formation. J. Biol. Chem. 1990, 265, 13702-13708.

(48) Congreve, M.; Langmead, C. J.; Mason, J. S.; Marshall, F. H. Progress in structure based drug design for $\mathrm{G}$ protein-coupled receptors. J. Med. Chem. 2011, 54, 4283-4311.

(49) Förster, T. Zwischenmolekulare energiewanderung und fluoreszenz. Ann. Phys. (Leipzig) 1948, 2, 55-75.

(50) Lazareno, S.; Popham, A.; Birdsall, N. J. M. Analogs of WIN 62,577 define a second allosteric site on muscarinic receptors. Mol. Pharmacol. 2002, 62, 1492-1505.

(51) Hulme, E. C.; Lu, Z. L.; Saldanha, J. W.; Bee, M. S. Structure and activation of muscarinic acetylcholine receptors. Biochem. Soc. Trans. 2003, 31, 29-34.

(52) Peng, J. Y.; Vaidehi, N.; Hall, S. E.; Goddard, W. A The predicted 3D structure of the human M1 muscarinic acetylcholine receptor with agonist and antagonist bound. ChemMedChem 2006, 1, $878-890$.

(53) Jakubik, J.; El-Fakahany, E. E.; Tucek, S. Evidence for a tandem two-site model of ligand binding to muscarinic acetylcholine receptors. J. Biol. Chem. 2000, 275, 18836-18844.

(54) Gregory, K. J.; Sexton, P. M.; Christopoulos, A. Allosteric modulation of muscarinic acetylcholine receptors. Curr. Neuropharmacol. 2007, 5, 157-167.

(55) Tränkle, C.; Weyand, O.; Voigländer, U.; Mynett, A.; Lazareno, S.; Birdsall, N. J. M.; Mohr, K. Interactions of orthosteric and allosteric ligands with $\left[{ }^{3} \mathrm{H}\right]$ dimethyl-W84 at the common allosteric site of muscarinic M2 receptors. Mol. Pharmacol. 2003, 64, 180-190.

(56) Palanché, T.; Ilien, B.; Zoffmann, S.; Reck, M.-P.; Bucher, B.; Edelstein, S.; Galzi, J.-L. The neurokinin A receptor activates calcium and cAMP responses through distinct conformational states. J. Biol. Chem. 2001, 276, 34853-34861.

(57) Christopoulos, A.; Sorman, J. L.; Mitchelson, F.; El-Fakahany, E. E. Characterization of the subtype selectivity of the allosteric modulator heptane-1,7-bis-(dimethyl-3'-phtalimidopropyl) ammonium bromide $\left(\mathrm{C}_{7} / 3\right.$-phth $)$ at cloned muscarinic acetylcholine receptors. Biochem. Pharmacol. 1999, 57, 171-179.

(58) Valant, C.; Gregory, K. J.; Hall, N. E.; Scammels, P. J.; Lew, M. J.; Sexton, P. M.; Christopoulos, A. A novel mechanism of G proteincoupled receptor functional selectivity. Muscarinic partial agonist 
McN-A-343 as a bitopic orthosteric/allosteric ligand. J. Biol. Chem. 2008, 283, 29312-29321.

(59) Narlawar, R.; Lane, J. R.; Doddareddy, M.; Lin, J.; Brussee, J.; Ijzerman, A. P. Hybrid ortho/allosteric ligands for the adenosine A1 receptor. J. Med. Chem. 2010, 53, 3028-3037.

(60) Antony, J.; Kellershohn, K.; Mohr-Andrä, M.; Kebig, A.; Prilla, S.; Muth, M.; Heller, E.; Disingrini, T.; Dallanoce, C.; Bertoni, S.; Schrobang, J.; Tränkle, C.; Kostenis, E.; Christopoulos, A.; Höltje, H. D.; Barocelli, E.; De Amici, M.; Holzgrabe, U.; Mohr, K. Dualsteric GPCR targeting: a novel route to binding and signaling pathway selectivity. FASEB J. 2009, 23, 442-450.

(61) Valant, C.; Sexton, P. M.; Christopoulos, A. Orthosteric/ allosteric bitopic hybrids. Going hybrid at GPCRs. Mol. Interventions 2009, 9, 125-135.

(62) Molecular Probes. http://www.probes.com/handbook/. 